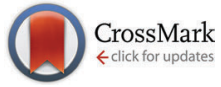

Cite this: New J. Chem., 2017, 41,735

Received (in Victoria, Australia) 20th September 2016,

Accepted 6th December 2016

DOI: 10.1039/c6nj02961b

www.rsc.org/njc

\section{Vanadium and zinc complexes of 5-cyanopicolinate and pyrazine derivatives: synthesis, structural elucidation and in vitro insulino-mimetic activity study $\dagger$}

\author{
Tanja Koleša-Dobravc, ${ }^{a}$ Keiichi Maejima, ${ }^{\text {b }}$ Yutaka Yoshikawa, ${ }^{c}$ Anton Meden, ${ }^{a}$ \\ Hiroyuki Yasui ${ }^{b}$ and Franc Perdih ${ }^{* a}$
}

\begin{abstract}
Vanadium(v) compounds with 5-cyanopicolinato acid (HpicCN), pyrazine-2-carboxylic acid (Hprz) and 3-aminopyrazine-2-carboxylic acid $\left(\mathrm{HprzNH}_{2}\right)$ and zinc compounds with $\mathrm{HpicCN}$ in the presence of 4-aminopyridine (4apy), pyridine (py) and 1,10-phenanthroline (phen) have been synthesized and characterized. The crystal structures of $\mathrm{NH}_{4}\left[\mathrm{VO}_{2}(\text { picCN) })_{2}\right]$ (3), $\mathrm{NH}_{4}\left[\mathrm{VO}_{2}(\mathrm{prz})_{2}\right](4), \mathrm{NH}_{4}\left[\mathrm{VO}_{2}\left(\mathrm{przNH}_{2}\right)_{2}\right] \cdot \mathrm{H}_{2} \mathrm{O}$ $\left(5 \cdot \mathrm{H}_{2} \mathrm{O}\right),\left[\mathrm{Zn}(\text { picCN })_{2}\left(\mathrm{H}_{2} \mathrm{O}\right)_{2}\right](6),\left[\mathrm{Zn}(\text { picCN })_{2}(4 a p y)_{2}\right] \cdot \mathrm{C}_{7} \mathrm{H}_{8}\left(7 \cdot \mathrm{C}_{7} \mathrm{H}_{8}\right),\left[\mathrm{Zn}(\text { picCN })_{2}(4 a p y)\right](8),\left[\mathrm{Zn}(\text { picCN })_{2}(\text { py })_{2}\right]$ (9) and $\left[\mathrm{Zn}(\text { picCN})_{2}\right.$ (phen)] $\cdot \mathrm{C}_{7} \mathrm{H}_{8} \cdot 2 \mathrm{MeOH}\left(\mathbf{1 0} \cdot \mathrm{C}_{7} \mathrm{H}_{8} \cdot 2 \mathrm{MeOH}\right)$ were determined by $\mathrm{X}$-ray crystallography. The spatial arrangements of all the vanadium(v) complexes are similar, having carboxylate oxygen atoms in a mutual trans orientation. In the zinc bis(5-cyanopicolinato) complexes three different arrangements were found with trans (6) and a cis (7, 9 and 10) octahedral and square-pyramidal (8) geometries. The insulinomimetic activity of selected $\mathrm{VO}(\mathrm{IV}), \mathrm{VO}_{2}(\mathrm{~V})$ and $\mathrm{Zn}(\mathrm{I})$ complexes was studied by in vitro inhibition of the free fatty acid (FFA) release from isolated rat adipocytes treated with epinephrine. All metal complexes showed insulino-mimetic activity and among them the VO(IV)-prz complex 2 was found to have higher insulinomimetic activity than the positive control. The other vanadium compounds have activities similar to $\mathrm{VOSO}_{4}$. The $\mathrm{Zn}$ complexes also exhibited some insulino-mimetic activity. Introduction of the $\mathrm{N}$-donor 4apy to the zinc picCN complex $\mathbf{8}$ significantly increased inhibition of FFA release compared to $\mathbf{6}$
\end{abstract}

\section{Introduction}

One of the most rapidly emerging diseases in the $21^{\text {st }}$ century is thought to be diabetes mellitus (DM). The worldwide number of patients suffering from DM was estimated to be 382 million in 2013 representing $\sim 8.3 \%$ of the adult population and is expected to increase to 592 million by $2035,{ }^{1}$ thus creating a significant health and economic burden. The prevalence of DM has been associated with ageing populations and the modern lifestyle, i.e. dietary changes, obesity, increasing urbanization,

\footnotetext{
${ }^{a}$ Faculty of Chemistry and Chemical Technology, University of Ljubljana, Večna pot 113, P. O. Box 537, SI-1000 Ljubljana, Slovenia. E-mail: franc.perdih@fkkt.uni-lj.si

${ }^{b}$ Department of Analytical and Bioinorganic Chemistry, Division of Analytical and Physical Chemistry, Kyoto Pharmaceutical University, 5 Nakauchi-cho, Misasagi, Yamashina-ku, Kyoto 607-8414, Japan

${ }^{c}$ Department of Health, Sports, and Nutrition, Faculty of Health and Welfare, Kobe Women's University, 4-7-2 Minatojima-nakamachi, Chuo-ku, Kobe, 650-0046, Japan

$\dagger$ Electronic supplementary information (ESI) available. CCDC 1480528-1480535 (3-10). For ESI and crystallographic data in CIF or other electronic formats see DOI: $10.1039 / \mathrm{c} 6 \mathrm{nj} 02961 \mathrm{~b}$
}

reduced physical activity, and increased stress. ${ }^{1,2} \mathrm{DM}$ is a condition characterized by abnormal glucose levels with a tendency for hyperglycaemia, due to a relative or absolute deficiency of insulin. DM is classified as type 1, type 2, or gestational diabetes. Type 2 represents the majority of diabetic patients $(\sim 90 \%)$ and is caused by insulin resistance or degradation of secreted insulin. It can be treated by dietary control, regular exercise and several chemotherapeutics or insulin. The most common treatment for diabetes is insulin. To some extent also oral hypoglycaemic drugs are used, however, they are often associated with undesirable side effects or a drop in efficacy is observed after prolonged use. ${ }^{3}$ Thus, the development of novel orally active compounds as an alternative to insulin injections as well as for the existing antidiabetics is still required and among the suitable candidates are zinc and vanadium coordination compounds.

In general, zinc and vanadium possess distinctly different biological roles in living organisms. Zinc is one of the most important trace elements in biological systems and is essential for the growth and development of microorganisms, plants and animals, and plays an important role in hundreds of metalloenzymes and in thousands of metalloproteins. ${ }^{4}$ In humans, zinc is the second most abundant trace element with an estimated 
total quantity of $2.3 \mathrm{~g}$, and only iron is more abundant than zinc. As an indispensable cation, zinc is a major regulatory ion in the metabolism of cells and presents many beneficial effects to human health. It has become apparent that zinc deficiency in humans is widely prevalent and significant; ${ }^{3-5}$ about $30 \%$ of the world's population is zinc deficient. ${ }^{6}$ Especially vulnerable are children under 5 years of age in developing countries and, for example, treatment of children suffering from deadly diarrhea with zinc significantly reduced child mortality in many third world countries. ${ }^{6}$ It has also been found that zinc is present in insulin, coordinated by three nitrogen atoms from histidine moieties and three water molecules. ${ }^{7}$ Contrary to zinc, functional vanadium compounds are scarcely present in living systems. Apart from some enzymes, such as vanadium-nitrogenase in nitrogen fixing bacteria and haloperoxidases, mainly present in marine algae, vanadium has been found in the form of amavadin, the storage proteins vanabins, and in the specialized blood cells, vanadocytes. ${ }^{8}$

It has been established that zinc complexes possess diverse biological activity, such as anticancer, ${ }^{9}$ antioxidant, ${ }^{10}$ antibacterial and antimicrobial activity, ${ }^{11}$ as well as having effects in the treatment of Alzheimer's disease. ${ }^{12}$ The biological functions of vanadium compounds, e.g. as antitumor, antiparasitic (Chagas disease), and osteogenic agents, have also been described.,13 Additionally, zinc and vanadium compounds have attracted increasing attention also due to their antidiabetic effects. A class of very promising complexes consists of neutral $\mathrm{Zn}$ and $\mathrm{V}$ species with bidentate anionic organic ligands, for example maltolato and ethylmaltolato complexes are more effective in lowering the glucose concentration in blood serum than the parent zinc or vanadium inorganic salts. ${ }^{14}$ Additionally, picolinato complexes were also found to be strong inhibitors of fatty acid mobilization and are active in the treatment of STZ-induced diabetic rats. ${ }^{15,16}$ Even better insulin-enhancing effects were observed for 6-methylpicolinato complexes. ${ }^{16,17}$ These initial successes stimulated subsequent tests of several zinc and vanadium complexes formed with picolinate derivatives, such as halopicolinato, 6-ethylpicolinato and 3-hydroxypicolinato ligands, ${ }^{3,18}$ and also species formed with monoesters and amides of 2,5-dipicolinic acid. ${ }^{19}$ Recent efforts have been oriented towards the synthesis of new compounds with high activity and low toxicity incorporating a variety of organic ligands including antioxidants ${ }^{20}$ affording different coordination environments. For example, complexes formed with allixin and $S$-allixin- $N$-methyl as well as with pyrrolidine- $N$-dithiocarbamato ligands have been demonstrated to be particularly active. ${ }^{21}$ Consequently, the field of antidiabetic zinc and vanadium compounds is gaining importance and novel compounds have been prepared and tested during the past few years. ${ }^{22}$ The recent development of noninvasive methods for analyzing and visualizing the biodistribution of complexes gave a fresh impetus in metallodrug discovery for the treatment of diabetes since it has been established that high antidiabetic activity correlates with a long retention time of complexes in the blood. ${ }^{23}$ Although clinical trials on an ethylmaltolato vanadium complex as an antidiabetic drug were abandoned due to side effects affecting the kidneys of the patients it is currently being studied as a therapeutic for the prevention, stoppage, and reparation of secondary tissue injuries. The main obstacle with the ethylmaltolato vanadium complex was the high dose necessary to achieve the therapeutic effect. ${ }^{14 f}$ In order to overcome this challenge Rehder ${ }^{8 b}$ has recently pointed out that ligands containing pyrone, pyridinone or pyridine-carboxylate moieties might be the best candidates with sufficiently long physiological half-lifes to recombine with metal ions in order to overcome the problem of retention of some vanadium in the body and thus to decrease the potential toxicity. ${ }^{24}$

In this respect we have revived interest in picolinato ligands and close analogues ${ }^{25}$ in order to established their structural characteristics and bioactivities. Herein we report eight vanadium and zinc compounds formed with 5-cyanopicolinic acid (HpicCN), pyrazine-2-carboxylic acid (Hprz) and 3-aminopyrazine-2-carboxylic acid $\left(\mathrm{HprzNH}_{2}\right)$. Structural characterization of all eight complexes was carried out by X-ray diffraction analysis. The insulino-mimetic activity of selected complexes was studied by in vitro inhibition of FFA release from isolated rat adipocytes treated with epinephrine.

\section{Experimental section}

\section{Materials and physical measurements}

Reagents and solvents were obtained from commercial suppliers as reagent grade and were used without further purification. Oxidovanadium(Iv), $\mathrm{VO}(\mathrm{Iv})$, compounds $\left[\mathrm{VO}(\text { picCN })_{2}\left(\mathrm{H}_{2} \mathrm{O}\right)\right] \cdot 2 \mathrm{H}_{2} \mathrm{O}$ $\left(\mathbf{1} \cdot 2 \mathrm{H}_{2} \mathrm{O}\right)$ and $\left[\mathrm{VO}(\mathrm{prz})_{2}\left(\mathrm{H}_{2} \mathrm{O}\right)\right](\mathbf{2})$ were synthesized from $\mathrm{VOSO}_{4}$. $5 \mathrm{H}_{2} \mathrm{O}$ and HpicCN or Hprz as described previously. ${ }^{25}$ Compound 4 was prepared by a modified synthetic procedure. ${ }^{26}$

Infrared (IR) spectra $\left(4000-600 \mathrm{~cm}^{-1}\right)$ of the samples were recorded using a Perkin-Elmer Spectrum 100, equipped with a Specac Golden Gate Diamond ATR as a solid sample support. Elemental (C, H, N) analyses were obtained using a Perkin-Elmer 2400 Series II CHNS/O Elemental Analyser. ${ }^{1} \mathrm{H}$ NMR spectra were recorded with Bruker Avance III 500 and Bruker Avance DPX 300 nuclear magnetic resonance spectrometers with DMSO and $\mathrm{D}_{2} \mathrm{O}$ as solvents and TMS as an internal reference.

\section{Synthesis}

Ammonium bis(5-cyanopicolinato- $\left.\kappa^{2} \mathrm{~N}, \mathrm{O}\right)$ dioxidovanadate(v) (3). Ammonium metavanadate ( $58 \mathrm{mg}, 0.50 \mathrm{mmol}$ ) was suspended in water $(5 \mathrm{~mL})$ and a solution of HpicCN $(124 \mathrm{mg}, 1.00 \mathrm{mmol})$ in methanol $(3 \mathrm{~mL})$ was added. The resulting solution was stirred under reflux for 15-30 min or until everything had dissolved. The solution obtained after hot filtration was stored at room temperature. After a few days of slow evaporation of the solvents, light yellow crystals had grown from the solution. Yield: $106 \mathrm{mg}, 54 \%$.

Elemental analysis $\left(\mathrm{C}_{14} \mathrm{H}_{10} \mathrm{~N}_{5} \mathrm{O}_{6} \mathrm{~V}\right)$ theoretical: $\mathrm{C}, 42.55 ; \mathrm{H}$, 2.55; N, 17.72. Found: C, 42.60; H, 2.52; N, 17.67\%.

IR (ATR, $\mathrm{cm}^{-1}$ ): 3162br, 3078br, 2847w, 2242w, 1680s, 1652s, $1601 \mathrm{~m}, 1477 \mathrm{~m}, 1424 \mathrm{w}, 1383 \mathrm{~m}, 1348 \mathrm{~m}, 1330 \mathrm{~s}, 1283 \mathrm{~m}, 1245 \mathrm{~m}$, $1152 \mathrm{~m}, 1035 \mathrm{~m}, 897 \mathrm{~s}, 868 \mathrm{~s}, 803 \mathrm{~m}, 788 \mathrm{w}, 686 \mathrm{~m}, 661 \mathrm{~m}$.

Ammonium bis(pyrazine-2-carboxylato- $\left.\kappa^{2} \mathrm{~N}, \mathrm{O}\right)$ dioxidovanadate(v) (4). Ammonium metavanadate $(58 \mathrm{mg}, 0.50 \mathrm{mmol})$ was suspended in water $(5 \mathrm{~mL})$ and a solution of Hprz $(124 \mathrm{mg}, 1.00 \mathrm{mmol})$ in methanol $(3 \mathrm{~mL})$ was added. The resulting solution was stirred 
under reflux for 15 min or until everything had dissolved. The solution obtained after hot filtration was stored at room temperature. After a few days of slow evaporation of the solvents, yellowish brown crystals had grown from the solution. Yield: $92 \mathrm{mg}, 53 \%$.

Elemental analysis $\left(\mathrm{C}_{10} \mathrm{H}_{10} \mathrm{~N}_{5} \mathrm{O}_{6} \mathrm{~V}\right)$ theoretical: $\mathrm{C}, 34.60 ; \mathrm{H}$, 2.90; N, 20.17. Found: C, 34.54; H, 2.69; N, 19.94\%.

IR (ATR, $\mathrm{cm}^{-1}$ ): 3018br, 2878w, 1674m, 1632m, 1592w, 1470w, $1420 \mathrm{~m}, 1350 \mathrm{~m}, 1321 \mathrm{~s}, 1283 \mathrm{w}, 1161 \mathrm{~m}, 1042 \mathrm{~s}, 896 \mathrm{~s}, 870 \mathrm{~m}, 861 \mathrm{~s}, 786 \mathrm{~s}$, 744m, 647w.

Ammonium bis(3-aminopyrazine-2-carboxylato- $\left.\kappa^{2} \mathrm{~N}, \mathrm{O}\right)$ dioxidovanadate(v) hydrate $\left(\mathbf{5} \cdot \mathbf{H}_{2} \mathbf{O}\right)$. Ammonium metavanadate $(58 \mathrm{mg}$, $0.50 \mathrm{mmol})$ was suspended in water $(5 \mathrm{~mL})$ and a solution of $\mathrm{HprzNH}_{2}$ (139 mg, $\left.1.00 \mathrm{mmol}\right)$ in methanol $(3 \mathrm{~mL})$ was added. The resulting solution was stirred under reflux for $15 \mathrm{~min}$ or until everything had dissolved. The solution obtained after hot filtration was stored at room temperature. After a few days of slow evaporation of the solvents, yellow crystals had grown from the solution. Yield: $123 \mathrm{mg}, 62 \%$.

Elemental analysis $\left(\mathrm{C}_{10} \mathrm{H}_{14} \mathrm{~N}_{7} \mathrm{O}_{7} \mathrm{~V}\right)$ theoretical: $\mathrm{C}, 30.39 ; \mathrm{H}$, 3.57; N, 24.81. Found: C, 30.40; H, 3.45; N, 24.6\%.

IR (ATR, $\mathrm{cm}^{-1}$ ): 3423m, 3172w, 2987m, 2875m, 1653s, $1597 \mathrm{~m}, 1555 \mathrm{w}, 1439 \mathrm{~m}, 1359 \mathrm{~s}, 1321 \mathrm{~m}, 1197 \mathrm{~m}, 1145 \mathrm{~s}, 907 \mathrm{~m}$, $875 \mathrm{~s}, 840 \mathrm{~m}, 817 \mathrm{~m}, 731 \mathrm{w}, 696 \mathrm{w}$.

trans-Di(aqua-кO)bis(5-cyanopicolinato- $\kappa^{2} N, O$ )zinc(II) (6). Zinc acetate dihydrate (59 $\mathrm{mg}, 0.25 \mathrm{mmol}$ ) was dissolved in water $(2 \mathrm{~mL})$ and a hot solution of HpicCN (74 $\mathrm{mg}, 0.50 \mathrm{mmol}$ ) in methanol $(5 \mathrm{~mL})$ was added. After addition a white precipitate formed in the mixture. The resulting suspension was stirred at $60{ }^{\circ} \mathrm{C}$ for an additional $20 \mathrm{~min}$ and was then cooled to room temperature. The white precipitate was filtered, washed with methanol and dried in air. Yield: $98 \mathrm{mg}, 99 \%$.

Elemental analysis $\left(\mathrm{C}_{14} \mathrm{H}_{10} \mathrm{~N}_{4} \mathrm{O}_{6} \mathrm{Zn}\right)$ theoretical: $\mathrm{C}, 42.50 ; \mathrm{H}$, 2.55; N, 14.16. Found: C, 42.63; H, 2.42; N, 14.10\%.

IR (ATR, $\mathrm{cm}^{-1}$ ): 3543w, 3066w, 2799w, 2239w, 1624s, 1597m, $1560 \mathrm{~m}, 1390 \mathrm{~m}, 1367 \mathrm{~s}, 1292 \mathrm{w}, 1253 \mathrm{w}, 1038 \mathrm{~m}, 1026 \mathrm{~m}, 890 \mathrm{w}$, $861 \mathrm{w}, 814 \mathrm{w}, 787 \mathrm{~m}, 687 \mathrm{~s}, 669 \mathrm{w}$.

cis-Di(4-aminopyridine- $\kappa N)$ bis(5-cyanopicolinato- $\left.\kappa^{2} N, O\right) z i n c(I I)-$ toluene (1/1) $\left(7 \cdot \mathbf{C}_{7} \mathbf{H}_{8}\right)$. Compound $6(20 \mathrm{mg}, 0.050 \mathrm{mmol})$ was suspended in toluene $(5 \mathrm{~mL})$ and then solid 4-aminopyridine (10 mg, $0.10 \mathrm{mmol}$ ) was added. The mixture was stirred for $10 \mathrm{~min}$ at $70{ }^{\circ} \mathrm{C}$, and then hot filtered and stored at room temperature. After a few days of slow evaporation of the solvents, colorless crystals had grown from the solution. Elemental analysis confirmed the content of 0.8 equivalents of toluene. Yield: $24 \mathrm{mg}, 77 \%$.

Elemental analysis $\left(\mathrm{C}_{29.6} \mathrm{H}_{24.4} \mathrm{~N}_{3} \mathrm{O}_{8} \mathrm{Zn}\right)$ theoretical: $\mathrm{C}, 57.19 ; \mathrm{H}$, 3.96; N, 18.03. Found: C, 57.21; H, 3.83; N, 18.14\%.

IR (ATR, $\mathrm{cm}^{-1}$ ): 3334w, 3172w, 2234w, 1610s, 1560m, 1519m, $1363 \mathrm{~s}, 1286 \mathrm{~m}, 1248 \mathrm{w}, 1210 \mathrm{~m}, 1032 \mathrm{w}, 1012 \mathrm{~s}, 853 \mathrm{~m}, 831 \mathrm{w}, 833 \mathrm{~m}$, 781m, 729w, 691m, 660w.

(4-Aminopyridine-к $N$ )bis(5-cyanopicolinato- $\kappa^{2} N, O$ )zinc(II) (8). Compound 6 (99 mg, $0.25 \mathrm{mmol}$ ) was suspended in methanol ( $5 \mathrm{~mL}$ ) and then solid 4-aminopyridine (48 $\mathrm{mg}, 0.50 \mathrm{mmol}$ ) was added. The mixture was stirred and heated under reflux for $30 \mathrm{~min}$, and then hot filtered and stored at room temperature. After a few days of slow evaporation of the solvents, colorless crystals had grown from the solution. Yield: $87 \mathrm{mg}, 38 \%$.
Elemental analysis $\left(\mathrm{C}_{19} \mathrm{H}_{12} \mathrm{~N}_{6} \mathrm{O}_{4} \mathrm{Zn}\right)$ theoretical: $\mathrm{C}, 50.30 ; \mathrm{H}$, 2.67; N, 18.52. Found: C, 49.92; H, 2.35; N, 18.23\%.

IR (ATR, $\mathrm{cm}^{-1}$ ): 3353m, 3198m, 2241w, 1655m, 1644m, $1645 \mathrm{~s}, 1567 \mathrm{~m}, 1525 \mathrm{~m}, 1388 \mathrm{w}, 1354 \mathrm{~s}, 1252 \mathrm{~m}, 1216 \mathrm{~m}, 1060 \mathrm{w}$, $1038 \mathrm{~m}, 1023 \mathrm{~s}, 858 \mathrm{~m}, 832 \mathrm{~m}, 808 \mathrm{~m}, 785 \mathrm{~m}, 690 \mathrm{~s}, 670 \mathrm{~m}$.

cis-Bis(5-cyanopicolinato- $\left.\kappa^{2} N, O\right) \operatorname{di}($ pyridine- $\kappa N)$ zinc(II) $(1 / 1)$ (9). Compound 6 (20 mg, $0.050 \mathrm{mmol}$ ) was dissolved in pyridine ( $5 \mathrm{~mL}, 62 \mathrm{mmol}$ ). The resulting solution was stirred for $10 \mathrm{~min}$ at $70{ }^{\circ} \mathrm{C}$, and then hot filtered and stored at room temperature. After a few days of slow evaporation of the solvents, colorless crystals had grown from the solution. The crystals decomposed when exposed to air. Elemental analysis shows that the pyridine moiety leaves the complex and crystal lattice out of solution, while it is replaced by water molecules. Yield: $15 \mathrm{mg}, 58 \%$.

Elemental analysis $\left(\mathrm{C}_{14} \mathrm{H}_{10} \mathrm{~N}_{4} \mathrm{O}_{6} \mathrm{Zn}\right)$ theoretical for $\mathrm{C}, 42.50$; H, 2.55; N, 14.16. Found: C, 42.48; H, 2.80; N, 14.71\%.

IR (ATR, cm ${ }^{-1}$ ): 3231br, 2233m, 1666s, 1602m, 1565m, 1391m, 1369s, 1253m, 1043m, 929w, 875m, 807m, 782m, 684s, 668m.

$\operatorname{Bis}\left(5\right.$-cyanopicolinato- $\left.\kappa^{2} N, O\right)\left(1,10\right.$-phenanthroline- $\left.\kappa^{2} N, N^{\prime}\right)$ zinc(II)-toluene-methanol (1/1/2) (10. $\left.\mathrm{C}_{7} \mathbf{H}_{8} \cdot \mathbf{2 M e O H}\right)$. Compound $6(20 \mathrm{mg}, 0.050 \mathrm{mmol})$ was suspended in toluene $(5 \mathrm{~mL})$ and then solid 1,10-phenanthroline ( $9 \mathrm{mg}, 0.05 \mathrm{mmol}$ ) was added. The resulting mixture was stirred for $10 \mathrm{~min}$ at $70{ }^{\circ} \mathrm{C}$ and then hot filtered. Methanol $(5 \mathrm{~mL})$ was added and the solution was stored at room temperature. After a few days of slow evaporation of the solvents, colorless crystals had grown from the solution. The crystals decomposed on air. Elemental analysis showed that an uncoordinated toluene moiety and methanol leave the crystal lattice and one equivalent of water is absorbed when crystals are exposed to air moisture. Yield: $16 \mathrm{mg}, 57 \%$.

Elemental analysis $\left(\mathrm{C}_{26} \mathrm{H}_{16} \mathrm{~N}_{6} \mathrm{O}_{5} \mathrm{Zn}\right)$ theoretical: $\mathrm{C}, 55.98 ; \mathrm{H}$, 2.89; N, 15.07. Found: C, 55.80; H, 2.76; N, 14.68\%.

IR (ATR, $\mathrm{cm}^{-1}$ ): 3422m, 3027w, 2240w, 1654s, $1597 \mathrm{~m}$, $1564 \mathrm{~m}, 1520 \mathrm{w}, 1476 \mathrm{w}, 1430 \mathrm{~m}, 1344 \mathrm{~s}, 1295 \mathrm{w}, 1249 \mathrm{~m}, 1211 \mathrm{w}$, $1103 \mathrm{w}, 1038 \mathrm{~m}, 847 \mathrm{~m}, 811 \mathrm{w}, 780 \mathrm{~m}, 725 \mathrm{~m}, 695 \mathrm{~m}, 664 \mathrm{~m}$.

\section{$\mathrm{X}$-ray structure determination}

Crystals suitable for X-ray analysis were obtained from compound solutions or filtered reaction mixtures at room temperature by slow evaporation of the solvents over a few days. Single-crystal $\mathrm{X}$-ray diffraction data were collected on either a Nonius Kappa CCD Diffractometer or an Agilent Technologies SuperNova Dual diffractometer with an Atlas detector using monochromated Mo-K $\alpha$ radiation $(\lambda=0.71073 \AA)$ or $\mathrm{Cu}-\mathrm{K} \alpha$ radiation $(\lambda=1.54184 \AA)$ at room temperature $(3,4,7,9)$ or at $150 \mathrm{~K}(\mathbf{5}, \mathbf{6 ,}, \mathbf{8}, \mathbf{1 0})$. The data were processed using DENZO or CrysAlis Pro. ${ }^{27}$ The structures were solved by direct methods using the program SHELXS-97 or SIR97 and refined on $F^{2}$ using full-matrix least-squares procedures (SHELXL-97 or SHELX2014). ${ }^{28}$ All non-hydrogen atoms were refined anisotropically. The hydrogen atoms on aromatic rings and $\mathrm{NH}_{2}$ groups were treated as riding atoms in geometrically idealized positions. Hydrogen atoms attached to water oxygen atoms or to the nitrogen atom of ammonium cations were readily located from difference Fourier maps and refined by fixing the bond lengths and isotropic temperature factors as $U_{\text {iso }}(\mathrm{H})=1.5 U_{\text {eq }}(\mathrm{O}, \mathrm{N})$. Two of the four methanol moieties in the 
structure of $\mathbf{1 0} \cdot \mathrm{C}_{7} \mathrm{H}_{8} \cdot 2 \mathrm{MeOH}$ are disordered over two positions with a refined ratio of $0.47: 0.53$, and the $\mathrm{C}-\mathrm{O}$ bond lengths were fixed on both disordered methanol solvate molecules. Crystallographic data are listed in Table S1 (ESI $\dagger$ ).

\section{In vitro insulin-like activity}

The procedure for the in vitro test was adopted from the literature. ${ }^{29}$ Male Wistar rats were sacrificed under anesthesia with ether. The adipose tissues were removed, chopped with scissors and digested with collagenase for $60 \mathrm{~min}$ at $37{ }^{\circ} \mathrm{C}$ in Krebs Ringer bicarbonate buffer $\left(120 \mathrm{mM} \mathrm{NaCl}, 1.27 \mathrm{mM} \mathrm{CaCl}_{2}\right.$, $1.2 \mathrm{mM} \mathrm{MgSO}_{4}, 4.75 \mathrm{mM} \mathrm{KCl}, 1.2 \mathrm{mM} \mathrm{KH}_{2} \mathrm{PO}_{4}, 24 \mathrm{mM} \mathrm{NaHCO}_{3}$ : $\mathrm{pH} 7.4$ ) containing $2 \%$ BSA (bovine serum albumin). The obtained adipocytes were then separated from the undigested tissues by filtration through a nylon mesh and washed three times. The metal complexes were dissolved in ultrapure water at $500 \mu \mathrm{M}$ (final conc.), glucose solution (final conc.; $5 \mathrm{mM}$ ) was added to the isolated adipocytes, and the resulting suspension was incubated at $37^{\circ} \mathrm{C}$ for $30 \mathrm{~min}$. Finally, epinephrine solution (final conc.; $10 \mu \mathrm{M}$ ) was added to the reaction mixtures, and the resulting solutions were incubated at $37{ }^{\circ} \mathrm{C}$ for $180 \mathrm{~min}$. The reactions were stopped by soaking in ice water, and the mixtures were centrifuged at $3000 \mathrm{rpm}$ for $10 \mathrm{~min}$. FFA (free fatty acids) levels in the outer solution of the cells were determined using an FFA kit (NEFA C-test WAKO, Wako Pure Chemicals).

All animal experiments in the present study were approved by the Experimental Animal Research of Kyoto Pharmaceutical University (KPU) and were performed according to the Guidelines for Animal Experimentation of KPU.

\section{Results and discussion}

\section{Synthesis and IR spectroscopy}

Oxidovanadium(Iv), VO(Iv), compounds 1 and 2 were synthesized from $\mathrm{VOSO}_{4} \cdot 5 \mathrm{H}_{2} \mathrm{O}$ and HpicCN or Hprz as described previously. ${ }^{25}$ Dioxidovanadate(v), $\mathrm{VO}_{2}(\mathrm{v})$, compounds were prepared from ammonium metavanadate and the corresponding picolinic acid analogues (HpicCN (3), Hprz (4) or $\mathrm{HprzNH}_{2}(5)$ ) in a $1: 2$ ratio in water. IR spectroscopy of 3-5 shows the presence of $\mathrm{N}-\mathrm{H}$ stretching vibrations of ammonium cations in the range between 3172 and $2847 \mathrm{~cm}^{-1}$ in all three compounds and stretching bands of $\mathrm{VO}_{2}{ }^{+}$cations were observed between 907 and $840 \mathrm{~cm}^{-1}$, while the characteristic absorption band for the cyano group in 3 was observed at $2242 \mathrm{~cm}^{-1}$.

Zinc bis(5-cyanopicolinato) complexes were prepared in two steps. In the first step a white powder of zinc bis(5-cyanopicolinato) compound (6) was prepared in a water/methanol mixture from zinc acetate dihydrate and HpicCN acid in a ratio of $1: 2$. In the second step 6 was suspended in an organic solvent and diluted after the addition of neutral $\mathrm{N}$-donor ligands 4apy $\left(7 \cdot \mathrm{C}_{7} \mathrm{H}_{8}, \mathbf{8}\right)$ or phen $\left(\mathbf{1 0} \cdot \mathrm{C}_{7} \mathrm{H}_{8} \cdot 2 \mathrm{MeOH}\right)$. Crystals of 9 were obtained by dissolving 6 in pure pyridine. 4Apy was selected to raise the hydrogen-bond formation potential through side amino groups. In addition, 4apy is already an FDA approved drug used in the treatment of multiple sclerosis as a blocker of potassium channels. ${ }^{30}$ Another two N-donors, pyridine and 1,10-phenanthroline, were used due to their structural similarity with 4 apy with the aim of comparing their binding modes. The outcome of the reactions with 4apy and py is strongly dependent on the solvent. When the synthesis of 4apy complexes was carried out in chloroform or a chloroform/toluene mixture two 4apy molecules were coordinated to zinc. On the contrary, in methanol only one 4apy coordinates to the zinc, even though the reactant ratio was $1: 2$. Reaction with py in methanol yielded crystals of diaqua complex 6 after exposing the solution to the air for a few days, and the pyridine complex 9 could be isolated only from pure pyridine. However, when crystals $\mathbf{9}$ were dried in air, the complex decomposed and transformed into the compound 6. IR spectra of $\mathbf{6}$ and 7-10 show characteristic absorption bands of the cyano group between 2241 and $2233 \mathrm{~cm}^{-1}$ and antisymmetric, $\nu_{\text {asym }}\left(\mathrm{CO}_{2}\right)$, and symmetric, $\nu_{\text {sym }}\left(\mathrm{CO}_{2}\right)$, stretching vibrations of the carboxylato group in the range $1666-1610 \mathrm{~cm}^{-1}$ and $1369-1344 \mathrm{~cm}^{-1}$, respectively, in all five compounds. The difference $\Delta$, a useful parameter for revealing the possible coordination mode of the carboxylato ligands, has values greater than $200 \mathrm{~cm}^{-1}$ for each of these complexes indicating a monodentate coordination of the carboxylate group. ${ }^{31}$ In the spectra of 7 and 8 an additional two bands in the range between 3353 and $3172 \mathrm{~cm}^{-1}$ are present corresponding to the $\mathrm{N}-\mathrm{H}$ stretching vibrations of amino groups.

\section{Structure of the complexes}

Crystal structures of $\mathrm{NH}_{4}\left[\mathrm{VO}_{2}(\text { picCN })_{2}\right](3), \mathrm{NH}_{4}\left[\mathrm{VO}_{2}(\mathrm{prz})_{2}\right]$ (4) and $\mathrm{NH}_{4}\left[\mathrm{VO}_{2}\left(\mathrm{przNH}_{2}\right)_{2}\right] \cdot \mathrm{H}_{2} \mathrm{O}\left(5 \cdot \mathrm{H}_{2} \mathrm{O}\right)$. Crystals of compounds 3-5 were grown from the reaction mixtures after a few days of slow evaporation of the solvents. Diagrams of the structures of complexes 3-5 are shown in Fig. 1-3, and selected bond distances and angles are summarized in Table 1 . The compounds crystallize in the monoclinic space group $P 2_{1} / c$ (3 and $5 \cdot \mathrm{H}_{2} \mathrm{O}$ ) and in the triclinic space group $P \overline{\mathbf{1}}$ (4). The asymmetric units contain a complex dioxidovanadate(v) anion and an ammonium cation ( 3 and $\mathbf{4}$ ), and in addition, in $\mathbf{5} \cdot \mathrm{H}_{2} \mathrm{O}$ one lattice water molecule is also present.

The vanadium atom in $\mathbf{3}$ is six-coordinated having an octahedral geometry with a cis arrangement of the oxido oxygen

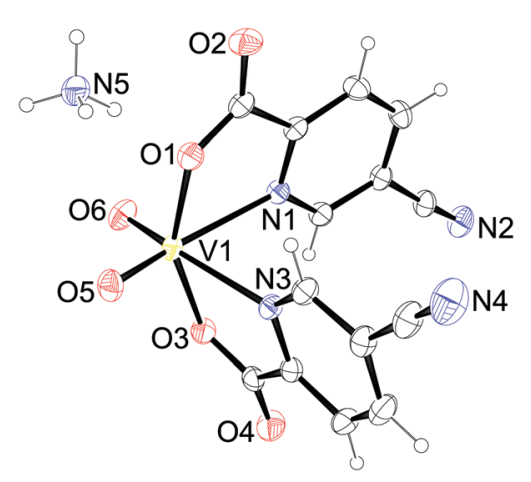

Fig. 1 Asymmetric unit of $\mathrm{NH}_{4}\left[\mathrm{VO}_{2}(\text { picCN) })_{2}\right]$ (3). Thermal ellipsoids are shown with a $30 \%$ probability level at $293 \mathrm{~K}$. 


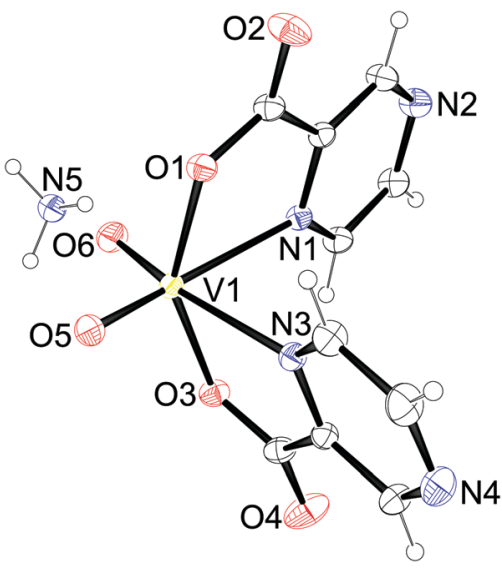

Fig. 2 Asymmetric unit of $\mathrm{NH}_{4}\left[\mathrm{VO}_{2}(\mathrm{prz})_{2}\right]$ (4). Thermal ellipsoids are shown with a $30 \%$ probability level at $293 \mathrm{~K}$.

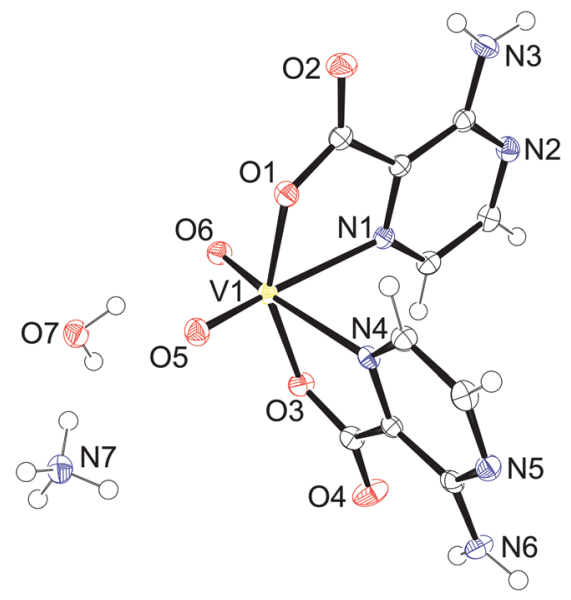

Fig. 3 Asymmetric unit of $\mathrm{NH}_{4}\left[\mathrm{VO}_{2}\left(\operatorname{przNH}_{2}\right)_{2}\right] \cdot \mathrm{H}_{2} \mathrm{O} \quad\left(\mathbf{5} \cdot \mathrm{H}_{2} \mathrm{O}\right)$. Thermal ellipsoids are shown with a $50 \%$ probability level at $150 \mathrm{~K}$.

atoms of the $\mathrm{VO}_{2}{ }^{+}$group and two bidentate 5-cyanopyridine-2carboxylate (picCN) ligands coordinated with picolinato nitrogen atoms trans to the oxido oxygen atoms $[\mathrm{V}-\mathrm{N}=2.3428(14)$ and 2.3275(15) $\AA$ ] and carboxylate oxygen atoms in a mutual trans orientation [V-O = 1.9824(12) and 1.9824(12) $\AA$ ]. The octahedral geometry displays a distortion with $\mathrm{O} 5-\mathrm{V} 1-\mathrm{N} 1$ and $\mathrm{O} 6-\mathrm{V} 1-\mathrm{N} 3$ angles of $160.75(6)^{\circ}$ and $162.91(6)^{\circ}$, respectively, and a O1-V1-O3 angle of $149.58(4)^{\circ}$.

Ammonium cations and complex anions in the crystal structure of $\mathbf{3}$ are connected into infinite double layers parallel to the $a c$ plane through several hydrogen bonds (Fig. S1, ESI + ). Each ammonium cation is as a hydrogen bond donor involved in six different hydrogen bonds, connected to four adjacent complex anions. Hydrogen bond acceptors in $\left[\mathrm{VO}_{2}(\text { picCN })_{2}\right]^{-}$are carbonyl, carboxyl and oxido oxygen atoms. Additional weak $\mathrm{C}-\mathrm{H} \cdots \mathrm{O}$ interactions are formed between the adjacent anions, but only within the same hydrogen-bonded layers. Hydrogen bonds and other weak intermolecular interactions in $\mathbf{3}$ are listed in Table S2 (ESI $\dagger$ ).

The vanadium atom in $\mathbf{4}$ and $\mathbf{5}$ is also six-coordinated having an octahedral geometry similar to 3 with a cis arrangement of the oxido oxygen atoms of the $\mathrm{VO}_{2}{ }^{+}$group and two bidentate
Table 1 Selected bond distances $(\AA)$ and angles $\left(^{\circ}\right)$ for $\mathrm{NH}_{4}\left[\mathrm{VO}_{2}(\text { picCN) })_{2}\right]$ (3), $\mathrm{NH}_{4}\left[\mathrm{VO}_{2}(\mathrm{prz})_{2}\right](4)$ and $\mathrm{NH}_{4}\left[\mathrm{VO}_{2}\left(\mathrm{przNH}_{2}\right)_{2}\right] \cdot \mathrm{H}_{2} \mathrm{O}\left(\mathbf{5} \cdot \mathrm{H}_{2} \mathrm{O}\right)$

\begin{tabular}{|c|c|c|c|}
\hline Distance (§̊) & 3 & 4 & $5 \cdot \mathrm{H}_{2} \mathrm{O}$ \\
\hline V1-O1 & $1.9824(13)$ & $2.0100(10)$ & $1.9831(12)$ \\
\hline $\mathrm{V} 1-\mathrm{O} 3$ & $1.9824(12)$ & $1.9619(10)$ & $1.9624(12)$ \\
\hline V1-O5 & $1.6236(13)$ & $1.6327(10)$ & $1.6255(12)$ \\
\hline V1-O6 & $1.6216(14)$ & $1.6243(10)$ & $1.6528(13)$ \\
\hline $\mathrm{V} 1-\mathrm{N} 1$ & $2.3434(14)$ & $2.3021(12)$ & $2.2914(14)$ \\
\hline $\mathrm{V} 1-\mathrm{N} 3 / 4^{a}$ & $2.3275(15)$ & $2.3075(12)$ & $2.2969(15)$ \\
\hline Angle $\left({ }^{\circ}\right)$ & 3 & 4 & $5 \cdot \mathrm{H}_{2} \mathrm{O}$ \\
\hline O1-V1-O3 & $153.78(5)$ & $149.59(4)$ & $154.47(5)$ \\
\hline O1-V1-O5 & $94.27(6)$ & 94.43(5) & $93.92(6)$ \\
\hline O1-V1-O6 & $102.25(7)$ & $99.82(5)$ & $100.47(6)$ \\
\hline O1-V1-N1 & 73.13(5) & $73.90(4)$ & $74.21(5)$ \\
\hline $\mathrm{O} 1-\mathrm{V} 1-\mathrm{N} 3 / 4^{a}$ & $87.05(5)$ & $82.22(4)$ & $86.46(5)$ \\
\hline O3-V1-O5 & $103.10(7)$ & $104.35(5)$ & $102.93(6)$ \\
\hline O3-V1-O6 & $92.46(6)$ & 98.18(5) & $93.36(6)$ \\
\hline O3-V1-N1 & $84.68(5)$ & $82.89(4)$ & $84.40(5)$ \\
\hline $\mathrm{O} 3-\mathrm{V} 1-\mathrm{N} 3 / 4^{a}$ & $73.89(5)$ & $74.81(4)$ & $74.85(5)$ \\
\hline O5-V1-O6 & $104.18(8)$ & $104.95(6)$ & $105.65(7)$ \\
\hline O5-V1-N1 & $160.75(6)$ & $164.90(5)$ & $161.66(6)$ \\
\hline $\mathrm{O} 5-\mathrm{V} 1-\mathrm{N} 3 / 4^{a}$ & $89.19(6)$ & $88.20(5)$ & $89.34(6)$ \\
\hline O6-V1-N1 & $92.89(7)$ & $86.78(5)$ & $90.47(6)$ \\
\hline O6-V1-N3/4 ${ }^{a}$ & $162.91(6)$ & $166.41(5)$ & $162.85(6)$ \\
\hline $\mathrm{N} 1-\mathrm{V} 1-\mathrm{N} 3 / 4^{a}$ & $75.93(5)$ & $80.85(4)$ & $76.23(5)$ \\
\hline
\end{tabular}

pyrazine-2-carboxylate (prz, $\mathrm{przNH}_{2}$ ) ligands coordinated with pyrazine nitrogen atoms trans to the oxido oxygen atoms [V-N = 2.3021(12), 2.3075(12) Å for 4 and 2.2914(14), 2.2969(15) Å for 5] and carboxylate oxygen atoms in a mutual trans orientation $[\mathrm{V}-\mathrm{O}=2.0100(10), 1.9619(10) \AA$ for 4 and 1.9831(12), 1.9624(12) $\mathrm{A}$ for 5]. The octahedral geometry displays a distortion with angles O5-V1-N1 of $164.90(5)^{\circ}, \mathrm{O} 6-\mathrm{V} 1-\mathrm{N} 3$ of $166.41(5)^{\circ}$ and O1-V1-O3 $149.58(4)^{\circ}$ in 4 and angles O5-V1-N1 of $161.66(6)^{\circ}, \mathrm{O} 6-\mathrm{V} 1-\mathrm{N} 4$ of $162.85(6)^{\circ}$ and $\mathrm{O} 1-\mathrm{V} 1-\mathrm{O} 3$ of $154.47(5)^{\circ}$ in 5.

Hydrogen bonds between the ammonium cations and heteroatoms of the complex anions in $\mathbf{4}$ enable the formation of hydrogen-bonded double layers parallel to the $a b$ plane (Fig. S2, ESI $\dagger$ ). The hydrogen bond acceptors in $\mathbf{4}$ are carbonyl and oxido oxygen atoms and the pyrazine nitrogen N2. The crystal structure is further stabilized by weak $\mathrm{C}-\mathrm{H} \cdots \mathrm{O}$ bonds and $\pi-\pi$ interactions with a $\mathrm{Cg} 4 \cdots \mathrm{Cg} 4$ centroid-to-centroid distance of 3.6544(11) A connecting adjacent layers along the $c$ axis (Tables S3 and S4, ESI $\dagger$ ). Extended hydrogen bonding connects ammonium cations, the complex anion and lattice water molecules in the crystal structure of $\mathbf{5} \cdot \mathrm{H}_{2} \mathrm{O}$ into a three dimensional network (Fig. S3, ESI $\dagger$ ) enhanced also by the presence of an amino group on the $\mathrm{przNH}_{2}$ ligand as a hydrogen bond donor. Crystal water acts as a hydrogen bond donor and acceptor, while carbonyl, carboxyl and oxido atoms and pyrazine N5 and amino N6 nitrogen atoms are involved as hydrogen bond acceptors. The crystal lattice is additionally stabilized by weak $\mathrm{C} 4-\mathrm{H} 4 \cdots \mathrm{O} 4$ bonds and $\pi-\pi$ interactions with $\mathrm{Cg} 3 \cdots \mathrm{Cg} 3$ and $\mathrm{Cg} 4 \cdots \mathrm{Cg} 4$ centroid-to-centroid distances of 3.5669(10) and 3.9506(9) A, respectively, connecting the complex anions along the $b$ axis (Fig. S4, Tables S5 and S6, ESI $\dagger$ ).

Crystal structures of $\left[\mathrm{Zn}(\text { picCN })_{2}\left(\mathrm{H}_{2} \mathrm{O}\right)_{2}\right](6)$, $\left[\mathrm{Zn}(\text { picCN })_{2}(4 a p y)_{2}\right]$. $\mathrm{C}_{7} \mathrm{H}_{8}\left(7 \cdot \mathrm{C}_{7} \mathrm{H}_{8}\right),\left[\mathrm{Zn}(\text { picCN })_{2}(4 a p y)\right](8),\left[\mathrm{Zn}(\text { picCN })_{2}(\mathrm{py})_{2}\right](9)$, and $\left[\mathrm{Zn}(\text { picCN})_{2}(\right.$ phen $\left.)\right] \cdot \mathrm{C}_{7} \mathrm{H}_{8} \cdot \mathbf{2 M e O H}\left(\mathbf{1 0} \cdot \mathrm{C}_{7} \mathrm{H}_{8} \cdot \mathbf{2 M e O H}\right)$. Crystals of 


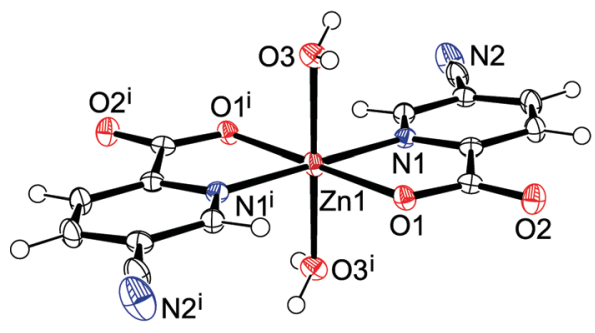

(a)

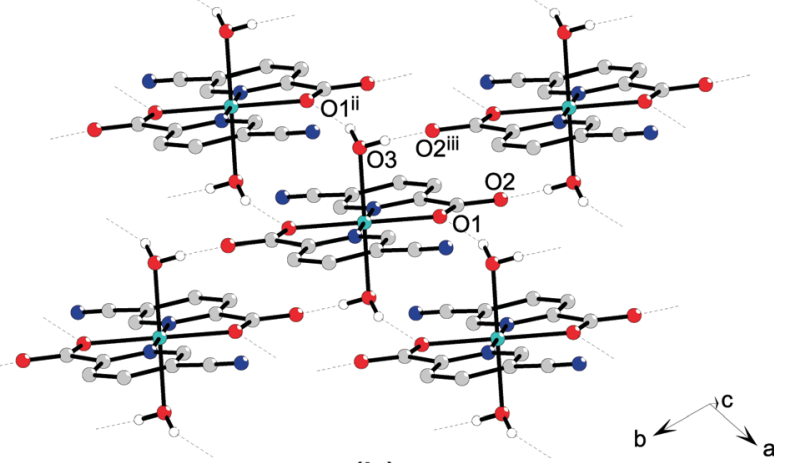

(b)

Fig. 4 (a) Structure of the compound $\left[\mathrm{Zn}(\mathrm{picCN})_{2}\left(\mathrm{H}_{2} \mathrm{O}\right)_{2}\right](6)$. Thermal ellipsoids are shown with a 50\% probability level at $150 \mathrm{~K}$. (b) The layer of hydrogenbonded molecules in 6 . Dashed lines indicate $\mathrm{O}-\mathrm{H} \ldots \mathrm{O}$ hydrogen bonds. Symmetry codes: (i) $-x+1,-y+1,-z+1 ;$ (ii) $x-1, y, z$; (iii) $-x+1,-y$, $-z+1$.

compounds 6-10 were grown from the reaction mixtures after a few days of slow evaporation of the solvents. Diagrams of the structures of complexes 6-10 are shown in Fig. 4-6, and selected bond distances and angles are summarized in Tables 2-4.

The complex 6 crystallizes in the triclinic space group $P \overline{1}$. The asymmetric unit contains one half of the complex with the zinc atom sitting on the inversion center. The zinc atom is octahedrally coordinated with two bidentate picCN ligands in the equatorial position in a trans arrangement and with two water molecules in the axial positions. The distance between the zinc and the carboxyl oxygen (Zn1-O1 = 2.0895(15) $\AA$ ) is shorter than the bond between the zinc and water $(\mathrm{Zn} 1-\mathrm{O} 3=$ 2.1118(18) ̊). The Zn1-N1 distance is 2.1306(19) A. The angles between the trans oriented atoms are $180^{\circ}$ due to the center of symmetry. The chelate angle of the picCN ligand O1-Zn1-N1 is $78.65(7)^{\circ}$, the angle between the water and the carboxyl oxygen atom $\mathrm{O} 1-\mathrm{Zn} 1-\mathrm{O} 3$ is $90.23(7)^{\circ}$, and the angle between the water and the picolinato nitrogen atom O3-Zn1-N1 is $92.32(7)^{\circ}$.
The crystal structure of $\mathbf{6}$ is stabilized by hydrogen bonding between a coordinated water molecule acting as a hydrogen bond donor and a carbonyl and carboxyl oxygen atoms as hydrogen bond acceptors forming hydrogen-bonded layers parallel to the $a b$ plane (Fig. 4 and Table S7, ESI $\dagger$ ). Furthermore, the coordinated water molecule is also an acceptor of a weak $\mathrm{C}-\mathrm{H} \cdots \mathrm{O}$ interaction formed with the picolinic $\mathrm{C}-\mathrm{H}$ moiety.

By reacting contacting 6 and 4apy two different crystals were prepared depending on the solvent used. Both syntheses were performed in a 1:2 molar ratio, however, in toluene crystals with two coordinated 4apy molecules were obtained (7), while synthesis in methanol yielded 8 with only one 4apy molecule coordinated to the zinc atom.

Compound 7 crystallizes as a toluene solvate in the triclinic space group $P \overline{1}$ with the formula $\left[\mathrm{Zn}(\text { picCN })_{2}(4 a p y)_{2}\right] \cdot \mathrm{C}_{7} \mathrm{H}_{8}$. The asymmetric unit contains one molecule of the complex and one molecule of toluene. The complex has a distorted octahedral

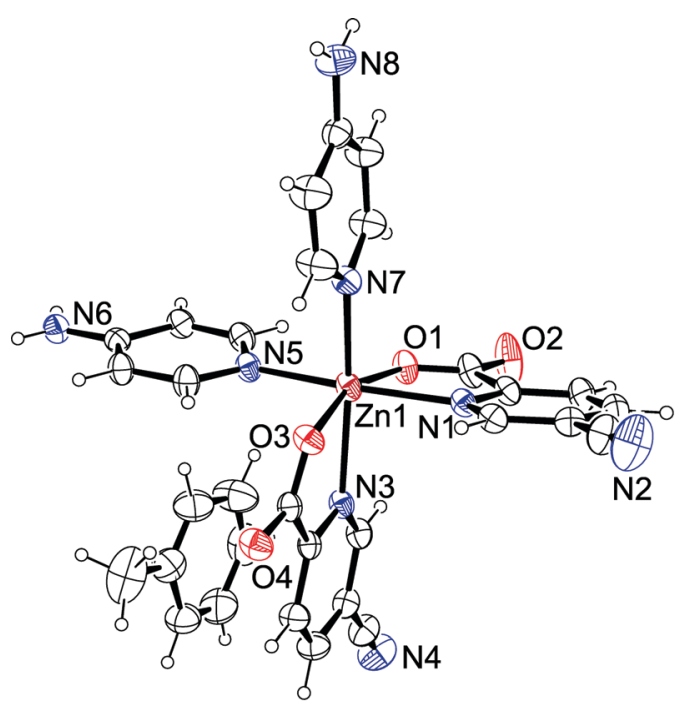

(a)

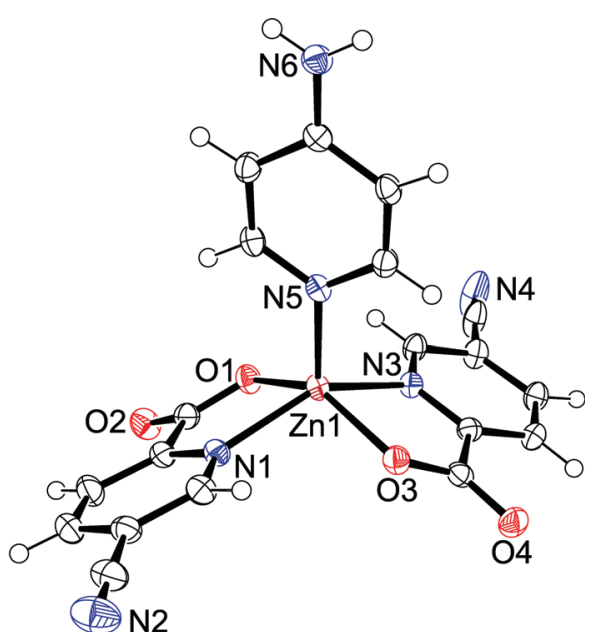

(b)

Fig. 5 Asymmetric unit of (a) $\left[\mathrm{Zn}(\mathrm{picCN})_{2}(4 a p y)_{2}\right] \cdot \mathrm{C}_{7} \mathrm{H}_{8}\left(\mathbf{7} \cdot \mathrm{C}_{7} \mathrm{H}_{8}\right)$. Thermal ellipsoids are shown with a $30 \%$ probability level at $293 \mathrm{~K}$. (b) $\left[\mathrm{Zn}(\mathrm{picCN})_{2}(4 \mathrm{apy})\right]$ (8). Thermal ellipsoids are shown with a $50 \%$ probability level at $150 \mathrm{~K}$. 


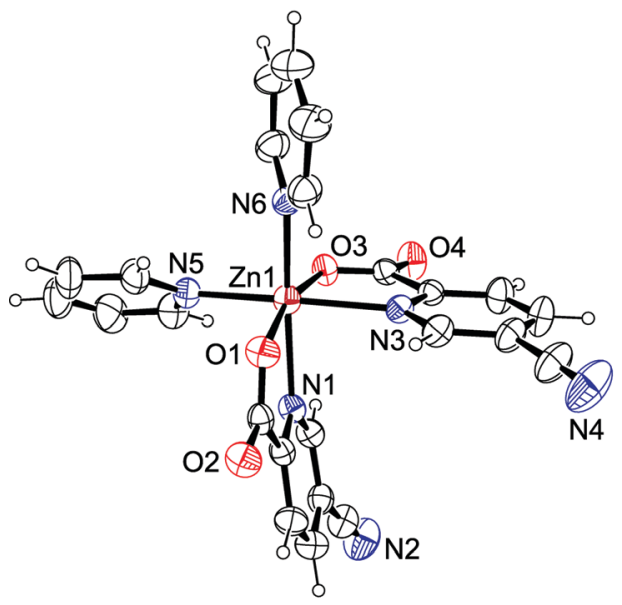

(a)

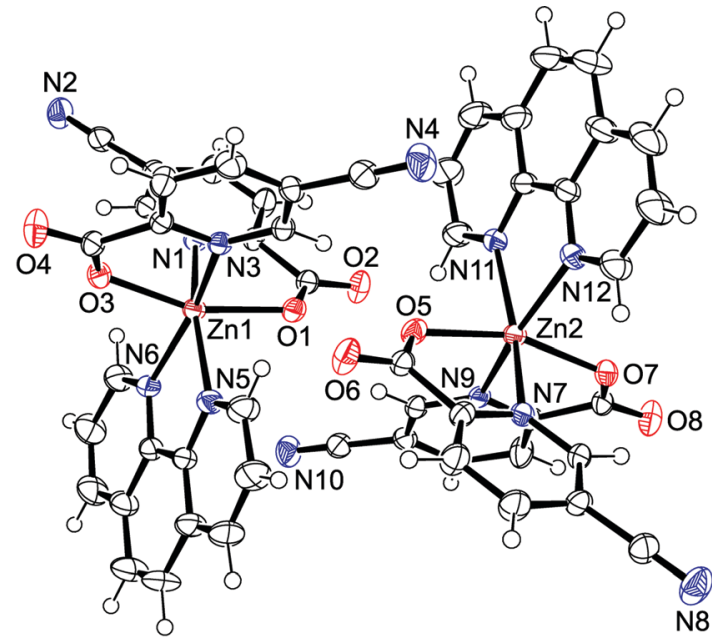

(b)

Fig. 6 (a) Asymmetric unit of $\left[\mathrm{Zn}(\operatorname{picCN})_{2}(\mathrm{py})_{2}\right]$ (9). Thermal ellipsoids are shown with a 30\% probability level at $293 \mathrm{~K}$. (b) Crystallographically independent molecules of $\left[\mathrm{Zn}(\text { picCN })_{2}(\right.$ phen)] (10). Solvate molecules have been removed for clarity. Thermal ellipsoids are shown with a $50 \%$ probability level at $150 \mathrm{~K}$.

Table 2 Selected bond distances $(\AA)$ and angles $\left(^{\circ}\right)$ for $\left[\mathrm{Zn}(\operatorname{picCN})_{2}\left(\mathrm{H}_{2} \mathrm{O}\right)_{2}\right]$ (6)

\begin{tabular}{|c|c|c|c|}
\hline Distance $(\AA)$ & 6 & \multirow{3}{*}{ Zn1-N1 } & \multirow{3}{*}{$2.1306(19)$} \\
\hline Zn1-O1 & 2.0895(15) & & \\
\hline Zn1-O3 & $2.1118(18)$ & & \\
\hline Angle $\left(^{\circ}\right)$ & 6 & & \\
\hline $\mathrm{O} 1-\mathrm{Zn} 1-\mathrm{O} 1^{\mathrm{i}}$ & $180.00(8)$ & $\mathrm{O} 3-\mathrm{Zn} 1-\mathrm{O} 3^{\mathrm{i}}$ & 180.0 \\
\hline O1-Zn1-O3 & $89.77(7)$ & O3-Zn1-N1 & $92.32(7)$ \\
\hline $\mathrm{O} 1-\mathrm{Zn} 1-\mathrm{O}^{\mathrm{i}}$ & $90.23(7)$ & $\mathrm{O} 3-\mathrm{Zn} 1-\mathrm{N} 1^{\mathrm{i}}$ & $87.68(7)$ \\
\hline O1-Zn1-N1 & $78.65(7)$ & $\mathrm{N} 1-\mathrm{Zn} 1-\mathrm{N} 1^{\mathrm{i}}$ & $180.00(1)$ \\
\hline $\mathrm{O} 1-\mathrm{Zn} 1-\mathrm{N} 1^{\mathrm{i}}$ & $101.35(7)$ & & \\
\hline
\end{tabular}

geometry, with a cis-octahedral arrangement of 4apy ligands on the zinc central atom. Two 4apy molecules are bound to the zinc through the pyridine nitrogen atoms with $\mathrm{Zn}-\mathrm{N}$ distances of 2.1256(18) and 2.1183(18) $\AA$ in cis positions with a N5-Zn1-N7 angle of $89.65(7)^{\circ}$, while the two bidentate picCN ligands are coordinated with the picolinato nitrogen atoms in a mutual cis position with Zn-N distances of 2.2246(17) and 2.2779(18) Å, being longer than those in compound 6. Carboxyl oxygen atoms are bound to the zinc atom in mutual trans positions $(\mathrm{O} 1-\mathrm{Zn} 1-\mathrm{O} 3=$ 161.02(7) ${ }^{\circ}$ with $\mathrm{Zn}-\mathrm{O}$ distances of 2.0845(14) and 2.0992(14) ̊).

The supramolecular structure of $7 \cdot \mathrm{C}_{7} \mathrm{H}_{8}$ is stabilized by $\mathrm{N}-\mathrm{H} \cdots \mathrm{O}$ hydrogen bonding between the amino groups of the 4apy ligands and the carbonyl oxygen atoms of the picCN ligands forming layers parallel to the $b c$ plane (Fig. S5 and Table S8, ESI $\dagger$ ). The crystal lattice is additionally stabilized by weak $\mathrm{C}-\mathrm{H} \cdots \pi$ and $\pi \cdots \pi$ interactions with a $\mathrm{Cg} 6 \cdot \mathrm{Cg} 7$ centroidto-centroid distance of 3.8672(1) Å between the toluene solvate molecule and the complex along the $b$ axis (Table S9, ESI $\dagger$ ).

$\left[\mathrm{Zn}(\text { picCN })_{2}(4 a p y)\right](8)$ crystallizes in the monoclinic space group $P 2_{1} / c$. The asymmetric unit contains one molecule of the complex. The central zinc atom is pentacoordinated with an
Table 3 Selected bond distances $(\AA)$ and angles ( ${ }^{\circ}$ ) for $\left[\mathrm{Zn}(\text { picCN })_{2}(4 a p y)_{2}\right]$. $\mathrm{C}_{7} \mathrm{H}_{8}\left(\mathbf{7} \cdot \mathrm{C}_{7} \mathrm{H}_{8}\right),\left[\mathrm{Zn}(\text { picCN) })_{2}(4 a p y)\right](8)$ and $\left[\mathrm{Zn}(\text { picCN })_{2}(\text { py })_{2}\right](\mathbf{9})$

\begin{tabular}{|c|c|c|c|}
\hline Distance $(\AA)$ & 7. $\mathrm{C}_{7} \mathrm{H}_{8}$ & 8 & 9 \\
\hline Zn1-O1 & $2.0845(14)$ & $2.0486(12)$ & $2.056(2)$ \\
\hline Zn1-O3 & $2.0992(14)$ & $2.0518(12)$ & $2.0483(18)$ \\
\hline Zn1-N1 & $2.2246(17)$ & $2.1309(15)$ & $2.240(2)$ \\
\hline Zn1-N3 & $2.2779(18)$ & $2.0953(14)$ & $2.222(2)$ \\
\hline Zn1-N5 & $2.1256(18)$ & $2.0088(14)$ & $2.138(2)$ \\
\hline $\mathrm{Zn} 1-\mathrm{N} 7 / 6^{a}$ & $2.1183(18)$ & - & $2.133(2)$ \\
\hline Angle $\left(^{\circ}\right)$ & 7. $\mathrm{C}_{7} \mathrm{H}_{8}$ & 8 & 9 \\
\hline O1-Zn1-O3 & $161.02(7)$ & $144.58(5)$ & 166.13(9) \\
\hline O1-Zn1-N1 & $76.60(6)$ & $78.59(5)$ & $76.94(8)$ \\
\hline O1-Zn1-N3 & $90.07(6)$ & $88.50(5)$ & $93.41(8)$ \\
\hline O1-Zn1-N5 & $94.93(6)$ & $113.92(6)$ & $96.90(9)$ \\
\hline $\mathrm{O} 1-\mathrm{Zn} 1-\mathrm{N} 7 / 6^{a}$ & $100.25(7)$ & - & $92.45(9)$ \\
\hline O3-Zn1-N1 & $91.40(6)$ & 92.95(5) & $91.87(8)$ \\
\hline O3-Zn1-N3 & $75.05(6)$ & 79.43(5) & $77.30(8)$ \\
\hline O3-Zn1-N5 & $96.94(7)$ & $101.49(5)$ & $91.25(8)$ \\
\hline $\mathrm{O} 3-\mathrm{Zn} 1-\mathrm{N} 7 / 6^{a}$ & $94.59(6)$ & - & $97.86(9)$ \\
\hline N1-Zn1-N3 & $89.83(6)$ & $145.82(6)$ & $85.18(8)$ \\
\hline N1-Zn1-N5 & $171.51(6)$ & $104.35(6)$ & $90.32(9)$ \\
\hline $\mathrm{N} 1-\mathrm{Zn} 1-\mathrm{N} 7 / 6^{a}$ & $91.28(7)$ & - & $168.29(9)$ \\
\hline N3-Zn1-N5 & $90.78(7)$ & 109.81(6) & $167.53(9)$ \\
\hline $\mathrm{N} 3-\mathrm{Zn} 1-\mathrm{N} 7 / 6^{a}$ & $169.60(6)$ & - & $90.61(9)$ \\
\hline N5-Zn1-N7/6 ${ }^{a}$ & $89.65(7)$ & - & $95.92(9)$ \\
\hline
\end{tabular}

almost ideal square-pyramidal coordination sphere. Distortion of the square pyramid can be best described by the structural parameter $\tau=(\alpha-\beta) / 60^{\circ}$, where $\alpha$ and $\beta$ are the largest angles in the coordination sphere ( $\tau=0$ for a square-pyramid and $\tau=1$ for a trigonal bipyramid), ${ }^{32}$ which in this case has a value of 0.02 . The axial coordination site is occupied by 4apy with the shortest $\mathrm{Zn}-\mathrm{N}$ distance among the reported compounds (2.0088(14) $\mathrm{A})$ and the bidentate picCN ligands are coordinated with a mutual trans arrangement in a basal plane with $\mathrm{Zn}-\mathrm{N}$ distances of 2.1309(15) and 2.0953(14) A and Zn-O distances of 
Table 4 Selected bond distances $(\AA)$ and angles $\left({ }^{\circ}\right)$ for $\left[\mathrm{Zn}(\text { picCN })_{2}(\right.$ phen $\left.)\right]$. $\mathrm{C}_{7} \mathrm{H}_{8} \cdot 2 \mathrm{MeOH}\left(\mathbf{1 0} \cdot \mathrm{C}_{7} \mathrm{H}_{8} \cdot 2 \mathrm{MeOH}\right)$

\begin{tabular}{llll}
\hline Distance $(\AA)$ & & & \\
\hline Zn1-O1 & $2.073(2)$ & Zn2-O5 & $2.064(2)$ \\
Zn1-O3 & $2.061(2)$ & Zn2-O7 & $2.069(2)$ \\
Zn1-N1 & $2.186(2)$ & Zn2-N7 & $2.196(2)$ \\
Zn1-N3 & $2.193(2)$ & Zn2-N9 & $2.185(2)$ \\
Zn1-N5 & $2.162(2)$ & Zn2-N11 & $2.169(2)$ \\
Zn1-N6 & $2.159(3)$ & Zn2-N12 & $2.153(2)$ \\
\hline
\end{tabular}

Angle $\left({ }^{\circ}\right)$

\begin{tabular}{lclc}
\hline O1-Zn1-O3 & $161.01(10)$ & O5-Zn2-O7 & $160.96(10)$ \\
O1-Zn1-N1 & $77.15(9)$ & O5-Zn2-N7 & $77.17(9)$ \\
O1-Zn1-N3 & $90.46(9)$ & O5-Zn2-N9 & $91.95(9)$ \\
O1-Zn1-N5 & $90.98(9)$ & O5-Zn2-N11 & $90.81(9)$ \\
O1-Zn1-N6 & $104.60(9)$ & O5-Zn2-N12 & $103.32(9)$ \\
O3-Zn1-N1 & $91.34(9)$ & O7-Zn2-N7 & $90.02(9)$ \\
O3-Zn1-N3 & $77.35(9)$ & O7-Zn2-N9 & $77.12(9)$ \\
O3-Zn1-N5 & $103.57(9)$ & O7-Zn2-N11 & $104.86(9)$ \\
O3-Zn1-N6 & $90.74(9)$ & O7-Zn2-N12 & $90.95(9)$ \\
N1-Zn1-N3 & $103.18(10)$ & N7-Zn2-N9 & $103.08(10)$ \\
N1-Zn1-N5 & $161.48(10)$ & N7-Zn2-N11 & $161.20(10)$ \\
N1-Zn1-N6 & $92.26(9)$ & N7-Zn2-N12 & $91.79(9)$ \\
N3-Zn1-N5 & $90.91(9)$ & N9-Zn2-N11 & $91.58(9)$ \\
N3-Zn1-N6 & $160.57(10)$ & N9-Zn2-N12 & $160.78(10)$ \\
N5-Zn1-N6 & $76.85(10)$ & N11-Zn2-N12 & $76.79(11)$ \\
& & &
\end{tabular}

2.0486(12) and 2.0518(12) A. All the observed Zn-N/O distances in 8 are shorter than the corresponding distances in 7 . The angle between the picolinato nitrogen atoms (N1-Zn1-N3) is $145.82(6)^{\circ}$, and the angle between the carboxylate oxygen atoms (O1-Zn1-O3) is $144.58(5)^{\circ}$. Angles between the 4apy pyridine nitrogen and the atoms of the picCN ligands are in the range of 101.49(5)-113.92(6) .

The supramolecular structure of 8 is stabilized with $\mathrm{N}-\mathrm{H} \cdots \mathrm{O}$ hydrogen bonding between adjacent molecules through the amino group of the 4apy ligand and the carbonyl oxygen atoms of picCN ligands forming layers parallel to the $b c$ plane (Fig. S6, ESI $\dagger$ ). Additionally, weak C6-H6 $\cdots \mathrm{N} 4$ and $\mathrm{C} 13-\mathrm{H} 13 \cdots \mathrm{O} 3$ interactions are formed enhancing the layer structure, while adjacent layers are connected through weak $\mathrm{C} 4-\mathrm{H} 4 \cdots \mathrm{O} 4$ interactions (Table S8, ESI $\dagger$ ).

$\left[\mathrm{Zn}(\text { picCN })_{2}(\mathrm{py})_{2}\right](9)$ crystallizes in the orthorhombic space group $P$ Pna $2_{1}$ and the asymmetric unit contains one molecule of the complex. The complex has a distorted octahedral geometry with the same cis-octahedral arrangement of the ligands as in 7. Two py molecules are bound to the zinc through the pyridine nitrogen atoms with $\mathrm{Zn}-\mathrm{N}$ distances of 2.138(2) and 2.133(2) $\AA$ in a cis position with a N5-Zn1-N6 angle of $95.92(9)^{\circ}$, while the two bidentate picCN ligands are coordinated with picolinato nitrogen atoms in a mutual cis position with $\mathrm{Zn}-\mathrm{N}$ distances of 2.240(2) and 2.222(2) A. Carboxyl oxygen atoms are bound to the zinc atom in mutual trans positions $\left(\mathrm{O} 1-\mathrm{Zn} 1-\mathrm{O} 3=166.13(9)^{\circ}\right.$ with $\mathrm{Zn}-\mathrm{O}$ distances of 2.056(2) and 2.0483(18) $\AA$ ).

In the crystal structure of $\mathbf{9}$ no classical hydrogen bonding is present. Stabilization of the crystal lattice in all three dimensions is due to weak $\mathrm{C}-\mathrm{H} \cdots \mathrm{O}$ interactions between the aromatic $\mathrm{C}-\mathrm{H}$ and the carbonyl oxygen and the cyano nitrogen atoms (Fig. S7 and Table S8, ESI $†$ ).
Compound 10 crystallizes in the monoclinic space group $P 2_{1} / c$ as a toluene methanol solvate $(1: 1: 2)$ with the formula $\left[\mathrm{Zn}(\text { picCN })_{2}(\right.$ phen $\left.)\right] \cdot \mathrm{C}_{7} \mathrm{H}_{8} \cdot 2 \mathrm{MeOH}$. The asymmetric unit contains two crystallographically independent complex molecules presented in Fig. 6, two molecules of toluene and four molecules of methanol. The two complex molecules in the asymmetric unit are $\Lambda^{-}$( $\left.\mathrm{Zn} 1\right)$ and $\Delta$-isomers $(\mathrm{Zn} 2)$ of 10. The distances and angles of both isomers are almost the same, therefore only one is discussed. The zinc central atom is hexacoordinated with the same octahedral arrangement as in 7 and 9. Phen is coordinated to the zinc with Zn-N distances of 2.162(2) and 2.159(3) $\AA$ and the picCN ligands with somewhat longer $\mathrm{Zn}-\mathrm{N}$ distances of 2.186(2) and 2.193(2) $\AA$ and $\mathrm{Zn}-\mathrm{O}$ distances of 2.073(2) and 2.061(2) $\AA$. The two picolinic nitrogen atoms are cis to each other $\left(\mathrm{N} 1-\mathrm{Zn} 1-\mathrm{N} 3=103.18(10)^{\circ}\right)$, and the two carboxyl oxygen atoms are in a trans arrangement $\left(\mathrm{O} 1-\mathrm{Zn} 1-\mathrm{O} 3=161.01(10)^{\circ}\right)$.

Methanol molecules are hydrogen bonded to the carbonyl oxygen atoms of the complex. The supramolecular structure is further stabilized in all three dimensions by weak $\mathrm{C}-\mathrm{H} \cdots \mathrm{O}$ and $\mathrm{C}-\mathrm{H} \cdots \mathrm{N}$ interactions formed between the aromatic picCN or phen protons and the carbonyl or carboxyl oxygen or the cyano nitrogen atoms. Furthermore, toluene is embedded in the structure by $\mathrm{C}-\mathrm{H} \cdots \pi$ interactions between the phen ligands and toluene as well as by $\pi \cdots \pi$ stacking interactions with centroid-to-centroid distances of 3.8752(17) and 3.9270(19) $\AA$ between the picCN rings and toluene along the $b$ axis (Fig. S8, Tables S9 and S10, ESI $\dagger$ ).

\section{Structural comparison}

Structure has a significant influence on the stability and biotransformation of the complexes as has been demonstrated for example for $\mathrm{VO}^{2+}$ species and their interactions with serum proteins by the use of EPR spectroscopy ${ }^{33}$ We are focusing on the diverse structural characteristics and supramolecular topologies of potential antidiabetic vanadium compounds. ${ }^{34}$ Recently, we have been studying $\mathrm{VO}^{2+}$ compounds with picolinic acid and pyrazine derivatives concerning their structures and interactions with proteins. Furthermore, we were able to establish the first crystallographic evidence for the formation of an isomer of a vanadyl bis(picolinato) complex with the two pyridine nitrogen atoms in a mutual trans position; the known structures possess a common arrangement with the two equatorial pyridine nitrogen atoms in a mutual cis position. ${ }^{25}$ We have extended the research also on $\mathrm{V}(\mathrm{v})$ and zinc compounds in order to verify the flexibility and diversity of spatial arrangements available in these species as well. A search in the Cambridge Structural Database (CSD) for mononuclear bisoxidovanadate(v) compounds with two picolinate or pyrazine-2-carboxylate ligands or derivatives revealed only three crystal structures. A compound synthesized by Gätjens et al. ${ }^{19 a}$ with 5-(methoxycarbonyl)picolinic acid and a compound prepared by Süss-Fink et $a .^{35}$ with pyrazine-2-carboxylic acid showing nitrogen atoms coordinated to the $\mathrm{V}$ metal center trans to the oxido oxygen atoms as observed also in 3-5 (Scheme 1(I)). Remarkably, different spatial orientation was found in $\mathrm{NH}_{4}\left[\mathrm{VO}_{2^{-}}\right.$ (pic) $\left.)_{2}\right] \cdot \mathrm{H}_{2} \mathrm{O}$ synthesized by Melchior et al. ${ }^{36}$ with one picolinato nitrogen atom coordinated to the $\mathrm{V}$ metal center trans to the 


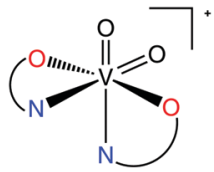

(I)

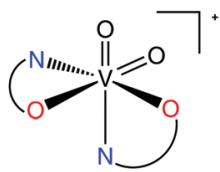

(II)

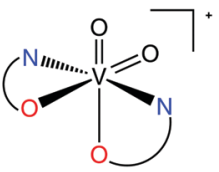

(III)
Scheme 1 Possible bis-chelated structures for $\mathrm{VO}_{2}{ }^{+}$species formed by a bidentate ligand.

oxido oxygen and the other picolinato nitrogen atom coordinated in a trans position to the carboxyl oxygen atom (Scheme 1(II)). Structures with the spatial arrangement as in isomer (III) (Scheme 1) have not been reported yet.

A search in the CSD for mononuclear neutral zinc compounds with two picolinate ligands or derivatives revealed 27 hexa- and penta-coordinated crystal structures with seven different spatial arrangements. The most frequent, with 16 compounds, is a trans-octahedral arrangement of ligands (Scheme 2(A)) as found, for example, in trans $\left[\mathrm{Zn}(\mathrm{pic})_{2}\left(\mathrm{H}_{2} \mathrm{O}\right)_{2}\right](\mathrm{Hpic}=$ picolinic acid) ${ }_{1}^{16}\left[\mathrm{Zn}(5 \mathrm{Mepic})_{2}\left(\mathrm{H}_{2} \mathrm{O}\right)_{2}\right](\mathrm{H} 5 \mathrm{Mepic}=5$-methylpicolinic acid $),{ }^{37}$ $\left[\mathrm{Zn}(\text { hypic })_{2}\left(\mathrm{H}_{2} \mathrm{O}\right)_{2}\right](\text { Hhypic }=3 \text {-hydroxypicolinic acid })^{38}$ and also in 6 . It is of interest to compare zinc compounds with the quinoline-2carboxylato (q2c) ligand in the presence of 1-methylimidazole (Meim) or imidazole (im) with [ $\left.\mathrm{Zn}(\mathrm{q} 2 \mathrm{c})_{2}(\mathrm{Meim})_{2}\right]$ possessing trans geometry $^{39}$ while $\left[\mathrm{Zn}(\mathrm{q} 2 \mathrm{c})_{2}(\mathrm{im})_{2}\right]$ possesses cis geometry with the carboxylato groups in a mutual trans position ${ }^{40}$ (Scheme 2(B)) as observed also in 7, 9 and 10. Another two possible cis spatial arrangements were found in cis- $\left[\mathrm{Zn}(\mathrm{pic})_{2}\left(\mathrm{H}_{2} \mathrm{O}\right)_{2}\right]^{41}$ (Scheme 2(C)) and in $\left[\mathrm{Zn}(\text { bipyc })_{2}\left(\mathrm{H}_{2} \mathrm{O}\right)_{2}\right]$ (Hbipyc $=4,4^{\prime}$-bipyridyl-2-carboxylic acid) (Scheme 2(D)) with the nitrogen atoms in a mutual trans position. ${ }^{42}$ Additionally, two structures have a coordinated bidentate phen ligand enforcing a cis orientation ${ }^{43}$ (Scheme 2(B)) as found also in 7, 9 and 10. Only 6 structures have been reported with a pentacoordinated arrangement. Out of these, five structures possess a trigonal-bipyramidal geometry: $\left[\mathrm{Zn}(6 \mathrm{Rpic})_{2}\left(\mathrm{H}_{2} \mathrm{O}\right)\right]$ (H6Rpic $=6$-methylpicolinic acid and 6-ethylpicolinic acid) ${ }^{17,44}$ $\left[\mathrm{Zn}(\mathrm{q} 2 \mathrm{c})_{2}\left(\mathrm{H}_{2} \mathrm{O}\right)\right]^{45}$ and $\left[\mathrm{Zn}(\mathrm{bp} 18 \mathrm{c} 6)_{2}\left(\mathrm{H}_{2} \mathrm{O}\right)\right]\left(\mathrm{H}_{2} \mathrm{bp} 18 \mathrm{c} 6=N, N^{\prime}-\right.$ bis[(6-carboxy-2-pyridyl)methyl]-4,13-diaza-18-crown-6 $)^{46}$ with the nitrogen donor atoms in an axial position (Scheme 2(E)), and $\left[\mathrm{Zn}\left(\mathrm{Hpycc}_{2}\left(\mathrm{H}_{2} \mathrm{O}\right)\right]\left(\mathrm{H}_{2}\right.\right.$ pycc $=$ pyridine-5-carboxylato-2-carboxylic

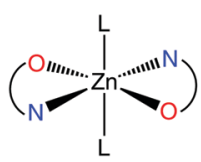

(A)

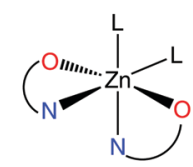

(B)

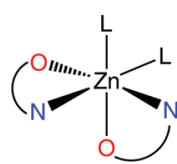

(C)

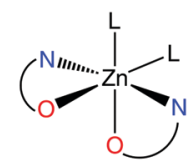

(D)

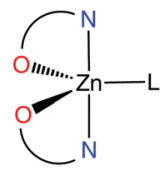

(E)

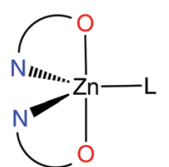

(F)

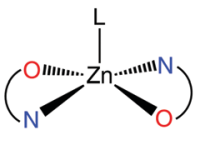

(G)
Scheme 2 Observed bis-chelated structures for $\mathrm{Zn}^{2+}$ species formed with a bidentate picolinato ligand and analogues in the presence of a neutral ligand $\mathrm{L}$. acid ${ }^{47}$ with the carboxylic oxygen atoms in an axial position (Scheme 2(F)) while only $\left[\mathrm{Zn}(\text { bupyc) })_{2}\left(\mathrm{H}_{2} \mathrm{O}\right)\right]$ (Hbupyc $=5$ butylpyridine-2-carboxylic acid $)^{48}$ possesses a square-pyramidal geometry (Scheme 2(G)) as observed in compound 8. These findings show the rich structural diversity that has to be taken into consideration in drug research and design.

\section{In vitro insulino-mimetic activity}

The insulin-like activities of the vanadium(Iv), ${ }^{25}$ vanadium(v) and two zinc(II) compounds prepared were evaluated by an in vitro experiment. The inhibitory effects on free fatty acid (FFA) release from isolated rat adipocytes treated with epinephrine were measured. Fig. 7 and 8 show the effects of the vanadium and zinc complexes on FFA release compared with those of ionic VS $\left(\mathrm{VOSO}_{4}\right)$ and $\mathrm{ZS}\left(\mathrm{ZnSO}_{4}\right)$, respectively. All metal complexes showed insulino-mimetic activity. The prz complex 2 was found to have a higher insulino-mimetic activity than the positive control (Fig. 7). The other vanadium compounds have activities similar to $\mathrm{VOSO}_{4}$. A comparison of $\mathbf{4}$ and $\mathbf{5}$ shows that the introduction of an amino group at position 3 of the pyrazine-2carboxylato ligand has no significant influence on the activity of the complex. $\mathrm{VO}(\mathrm{Iv})$ compounds exhibit higher activity than $\mathrm{VO}_{2}(\mathrm{v})$ species and this is in agreement with previous findings ${ }^{24}$ and can be attributed to the different redox behavior of vanadium species, ${ }^{49}$ the different mechanism of cellular uptake ${ }^{50}$ or the different speciation in the cytosol..$^{51}$ Additionally, it has been also proposed that $\left[\mathrm{VO}(\mathrm{rv})(\mathrm{OH})_{3}\right]^{-}$could be the active species. ${ }^{8}$

The zinc complexes also exhibited some insulino-mimetic activity, but the insulino-mimetic activity of these complexes was not more potent than that of $\mathrm{ZnSO}_{4}$ (Fig. 8). Interestingly, the introduction of an $\mathrm{N}$-donor 4apy to the zinc picCN complex

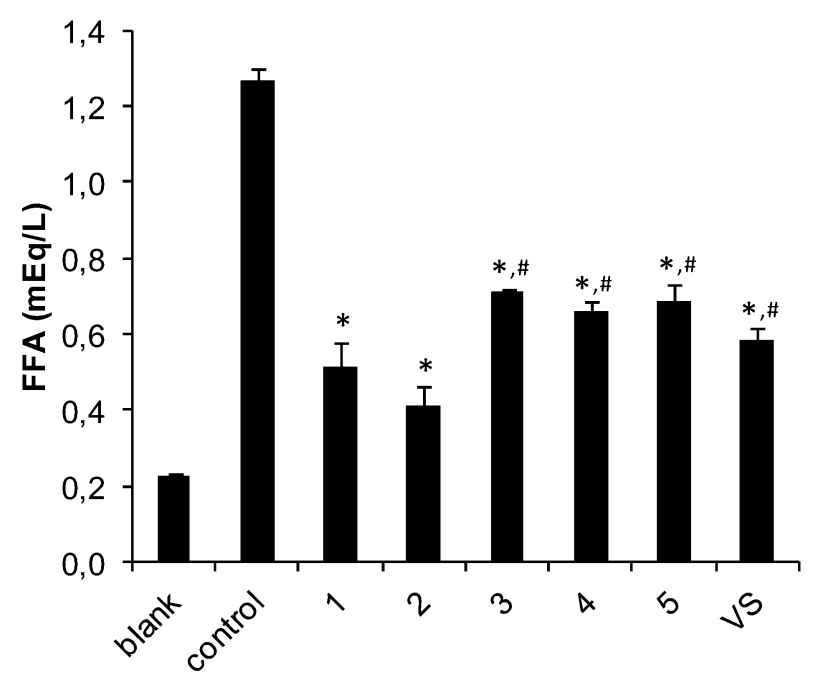

Fig. 7 Inhibitory effects of vanadium complexes (1-5) and $\mathrm{VOSO}_{4}$ (VS) on free fatty acid release from isolated rat adipocytes treated with epinephrine. The blank represents cells only and the control represents cells plus $10 \mu \mathrm{M}$ epinephrine solution. Data are expressed as the means \pm SDs for three experiments at a $0.5 \mathrm{mM}$ concentration in water. Significant differences were analyzed by one-way analysis of the variance and Tukey test. *: $p<0.01$ vs. control, and \#: $p<0.01$ vs. compound 2 . 


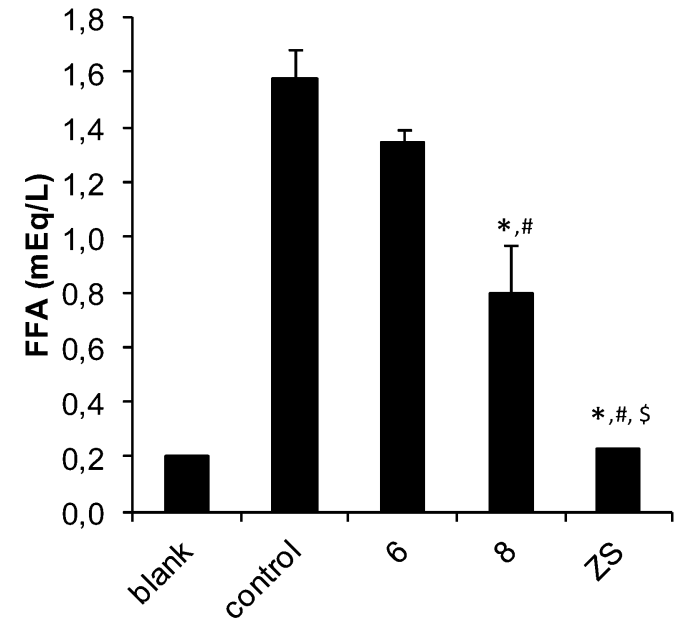

Fig. 8 Inhibitory effects of zinc complexes (6 and $\mathbf{8}$ ) and $\mathrm{ZnSO}_{4}(\mathrm{ZS})$ on free fatty acid release from isolated rat adipocytes treated with epinephrine. The blank represents cells only and the control represents cells plus $10 \mu \mathrm{M}$ epinephrine solution. Data are expressed as the means \pm SDs for three experiments at a $0.5 \mathrm{mM}$ concentration in water. Significant differences were analyzed by one-way analysis of the variance and Tukey test. $*: p<0.01$ vs. control, \#: $p<0.01$ vs. compound 6 , and $\$: p<0.01$ vs. compound 8 .

8 significantly increased inhibition of the FFA release compared to 6 .

\section{Conclusion}

Three vanadium(v) compounds with 5-cyanopicolinato acid (HpicCN), pyrazine-2-carboxylic acid (Hprz) and 3-aminopyrazine-2carboxylic acid $\left(\mathrm{HprzNH}_{2}\right)$ and five zinc compounds with HpicCN in the presence of water, 4-aminopyridine (4apy), pyridine (py) and 1,10-phenanthroline (phen) have been prepared and characterized. The crystal structures of $\mathrm{NH}_{4}\left[\mathrm{VO}_{2}(\text { picCN })_{2}\right](3), \mathrm{NH}_{4}\left[\mathrm{VO}_{2}(\mathrm{prz})_{2}\right]$ (4), and $\mathrm{NH}_{4}\left[\mathrm{VO}_{2}\left(\text { przNH}_{2}\right)_{2}\right] \cdot \mathrm{H}_{2} \mathrm{O}\left(\mathbf{5} \cdot \mathrm{H}_{2} \mathrm{O}\right)$ possess similar spatial arrangements with the carboxylate oxygen atoms in a mutual trans orientation although the carboxylate oxygen atoms in the prototypical complex $\mathrm{NH}_{4}\left[\mathrm{VO}_{2}(\text { pic })_{2}\right]$ are positioned in a mutual cis orientation. In the zinc bis(5-cyanopicolinato) complexes $\left[\mathrm{Zn}(\text { picCN })_{2}\left(\mathrm{H}_{2} \mathrm{O}\right)_{2}\right] \quad(6), \quad\left[\mathrm{Zn}(\text { picCN })_{2}(4 \mathrm{apy})_{2}\right] \cdot \mathrm{C}_{7} \mathrm{H}_{8} \quad\left(7 \cdot \mathrm{C}_{7} \mathrm{H}_{8}\right)$, $\left[\mathrm{Zn}(\text { picCN })_{2}(4 \mathrm{apy})\right](\mathbf{8}),\left[\mathrm{Zn}(\text { picCN })_{2}(\text { py })_{2}\right](\mathbf{9})$, and $\left[\mathrm{Zn}(\text { picCN })_{2^{-}}\right.$ (phen)] $\mathrm{C}_{7} \mathrm{H}_{8} \cdot 2 \mathrm{MeOH}\left(\mathbf{1 0} \cdot \mathrm{C}_{7} \mathrm{H}_{8} \cdot 2 \mathrm{MeOH}\right)$ three different arrangements were found with trans (6) and cis (7, 9 and 10) octahedral and square-pyramidal (8) geometries. The "4apy" ligand forms two different compounds, $\left[\mathrm{Zn}(\text { picCN })_{2}(4 a p y)_{2}\right] \cdot \mathrm{C}_{7} \mathrm{H}_{8} \quad\left(7 \cdot \mathrm{C}_{7} \mathrm{H}_{8}\right)$ with a cis-octahedral and $\left[\mathrm{Zn}(\text { picCN })_{2}(4\right.$ apy) $](8)$ with a squarepyramidal geometry depending on the polarity of the solvent used (chloroform/toluene vs. methanol). Attempts were made to prepare analogues of $\mathbf{7}$ and $\mathbf{8}$ with a py ligand, however only cisoctahedral 9 was isolated with pyridine as the solvent and a diaqua complex $\mathbf{6}$ from a methanol solution. Interestingly, $\mathbf{8}$ transformed to $\mathbf{6}$ on standing in air. The diverse spatial arrangements observed indicate the structural flexibility, a property useful in the process of molecular recognition and formation of compound-protein complexes. The insulino-mimetic activity of $\mathrm{VO}(\mathrm{Iv})(\mathbf{1}, 2) \mathrm{VO}_{2}(\mathrm{v})(3-5)$ and $\mathrm{Zn}$ (II) complexes (6 and 8) was studied by in vitro inhibition of free fatty acid (FFA) release from isolated rat adipocytes treated with epinephrine. All selected metal complexes showed insulino-mimetic activity. The vanadium(Iv) complex prz 2 was found to have a higher insulino-mimetic activity than the positive control. The other vanadium compounds have activities similar to $\mathrm{VOSO}_{4}$. The $\mathrm{Zn}$ complexes also exhibited some insulino-mimetic activity. The introduction of an N-donor 4apy to the zinc picCN complex 8 significantly increased the inhibition of FFA release compared to 6 .

\section{Acknowledgements}

The authors thank the Slovenian Research Agency for financial support (P1-0230-0175) as well as the EN-FIST Centre of Excellence, Slovenia for use of the Supernova diffractometer.

\section{References}

1 IDF Diabetes Atlas, International Diabetes Federation, 6th edn, 2013.

2 L. Guariguata, D. R. Whiting, I. Hambleton, J. Beagley, U. Linnenkamp and J. E. Shaw, Diabetes Res. Clin. Pract., 2014, 103, 137-149.

3 Y. Yoshikawa and H. Yasui, Curr. Top. Med. Chem., 2012, 12, 210-218.

4 C. T. Chasapis, A. C. Loutsidou, C. A. Spiliopoulou and M. E. Stefanidou, Arch. Toxicol., 2011, 86, 521-534.

5 K. Jurowski, B. Szewczyk, G. Nowak and W. Piekoszewski, J. Biol. Inorg. Chem., 2014, 19, 1-11.

6 G. Vardatsikos, N. R. Pandey and A. K. Srivastava, J. Inorg. Biochem., 2013, 120, 8-17.

7 E. Ciszak and G. D. Smith, Biochemistry, 1994, 33, 1512-1517.

8 (a) D. C. Crans, J. J. Smee, E. Gaidamauskas and L. Yang, Chem. Rev., 2004, 104, 849-902; (b) D. Rehder, Future Med. Chem., 2012, 4, 1823-1837; (c) D. Rehder, Dalton Trans., 2013, 42, 11749-11761; (d) J. Costa Pessoa, E. Garribba, M. F. A. Santos and T. Santos-Silva, Coord. Chem. Rev., 2015, 301-302, 49-86; (e) D. Rehder, Future Med. Chem., 2016, 8, 325-338.

9 (a) E. Mrkalić, A. Zianna, G. Psomas, M. Gdaniec, A. Czapik, E. Coutouli-Argyropoulou and M. Lalia-Kantouri, J. Inorg. Biochem., 2014, 134, 66-75; (b) A. Zianna, G. Psomas, A. Hatzidimitriou, E. Coutouli-Argyropoulou and M. LaliaKantouri, J. Inorg. Biochem., 2013, 127, 116-126; (c) A. Tarushi, E. Polatoglou, J. Kljun, I. Turel, G. Psomas and D. P. Kessissoglou, Dalton Trans., 2011, 40, 9461-9473.

10 (a) A. Tarushi, X. Totta, A. Papadopoulos, J. Kljun, I. Turel, D. P. Kessissoglou and G. Psomas, Eur. J. Med. Chem., 2014, 74, 187-198; (b) A. Tarushi, Z. Karaflou, J. Kljun, I. Turel, G. Psomas, A. N. Papadopoulos and D. P. Kessissoglou, J. Inorg. Biochem., 2013, 128, 85-96.

11 A. Tarushi, K. Lafazanis, J. Kljun, I. Turel, A. A. Pantazaki, G. Psomas and D. P. Kessissoglou, J. Inorg. Biochem., 2013, 121, 53-65. 
12 H. Kozlowski, M. Luczkowski, M. Remelli and D. Valensin, Coord. Chem. Rev., 2012, 256, 2129-2141.

13 D. Gambino, Coord. Chem. Rev., 2011, 255, 2193-2203.

14 (a) K. H. Thompson and C. Orvig, J. Inorg. Biochem., 2006, 100, 1925-1935; (b) K. H. Thompson, J. Lichter, C. LeBel, M. C. Scaife, J. H. McNeill and C. Orvig, J. Inorg. Biochem., 2009, 103, 554-558; (c) Y. Yoshikawa, E. Ueda, H. Miyake, H. Sakurai and Y. Kojima, Biochem. Biophys. Res. Commun., 2001, 281, 1190-1193; (d) Y. Adachi, J. Yoshida, Y. Kodera, A. Kato, Y. Yoshikawa, Y. Kojima and H. Sakurai, J. Biol. Inorg. Chem., 2004, 9, 885-893; (e) J. Costa Pessoa, S. Etcheverry and D. Gambino, Coord. Chem. Rev., 2015, 301-302, 24-48; $(f)$ K. D. Mjos and C. Orvig, Chem. Rev., 2014, 114, 4540-4563.

15 H. Sakurai, K. Fujii, H. Watanabe and H. Tamura, Biochem. Biophys. Res. Commun., 1995, 214, 1095-1101.

16 Y. Yoshikawa, E. Ueda, K. Kawabe, H. Miyake, T. Takino, H. Sakurai and Y. Kojima, J. Biol. Inorg. Chem., 2002, 7, 68-73.

17 (a) S. Fujimoto, K. Fujii, H. Yasui, R. Matsushita, J. Takada and H. Sakurai, J. Clin. Biochem. Nutr., 1997, 23, 113-129; (b) Y. Fujisawa and H. Sakurai, Chem. Pharm. Bull., 1999, 47, 1668-1670.

18 (a) H. Sakurai, Y. Yoshikawa and H. Yasui, Chem. Soc. Rev., 2008, 37, 2383-2392; (b) H. Sakurai, Y. Kojima, Y. Yoshikawa, K. Kawabe and H. Yasui, Coord. Chem. Rev., 2002, 226, 187-198.

19 (a) J. Gätjens, B. Meier, T. Kiss, E. M. Nagy, P. Buglyó, H. Sakurai, K. Kawabe and D. Rehder, Chem. - Eur. J., 2003, 9, 4924-4935; (b) J. Gätjens, B. Meier, Y. Adachi, H. Sakurai and D. Rehder, Eur. J. Inorg. Chem., 2006, 3575-3585; (c) H. Esbak, E. A. Enyedy, T. Kiss, Y. Yoshikawa, H. Sakurai, E. Garribba and D. Rehder, J. Inorg. Biochem., 2009, 103, 590-600.

20 Y. Wei, C. Zhang, P. Zhao, X. Yang and K. Wang, J. Inorg. Biochem., 2011, 105, 1081-1085.

21 (a) Y. Adachi, J. Yoshida, Y. Kodera, A. Katoh, J. Takada and H. Sakurai, J. Med. Chem., 2006, 49, 3251-3256; (b) M. Hiromura, Y. Adachi, M. Machida, M. Hattori and H. Sakurai, Metallomics, 2009, 1, 92-100; (c) Y. Adachi, J. Yoshida, Y. Kodera and H. Sakurai, Chem. Lett., 2005, 34, 656-657; (d) Y. Yoshikawa, Y. Adachi and H. Sakurai, Life Sci., 2007, 80, 759-766.

22 (a) T. Moroki, Y. Yoshikawa, K. Yoshizawa, A. Tsubura and H. Yasui, Metallomics, 2014, 6, 1632-1638; (b) M. E. LópezViseras, B. Fernández, S. Hilfiker, C. S. González, J. L. González, A. J. Calahorro, E. Colacio and A. RodríguezDiéguez, J. Inorg. Biochem., 2014, 131, 64-67; (c) N. Domingues, J. Pelletier, C.-G. Ostenson and M. M. C. A. Castro, J. Inorg. Biochem., 2014, 131, 115-122; (d) S. I. Pillai, S. P. Subramanian and M. Kandaswamy, Eur. J. Med. Chem., 2013, 63, 109-117; (e) Y. Yoshikawa, A. Murayama, Y. Adachi, H. Sakurai and H. Yasui, Metallomics, 2011, 3, 686-692; $(f)$ H. Kawarada, Y. Yoshikawa, H. Yasui, S. Kuwahara, Y. Habata and R. Saito, Metallomics, 2011, 3, 675-679; $(g)$ B. Fernández, A. GómezVílchez, C. Sánchez-González, J. Bayón, E. San Sebastián, S. Gómez-Ruiz, C. López-Chaves, P. Aranda, J. Llopis and A. Rodríguez-Diéguez, New J. Chem., 2016, 40, 5387-5393; (h) Z.-Q. Han, S. Han and Y. Wang, Acta Chim. Slov., 2016, 63, 200-203; (i) J.-X. Lei, J. Wang, Y. Huo and Z. You, Acta Chim. Slov., 2016, 63, 670-677.

23 (a) M. Munekane, S. Motomura, S. Kamino, M. Ueda, H. Haba, Y. Yoshikawa, H. Yasui, M. Hiromura and S. Enomoto, Biochem. Biophys. Rep., 2016, 5, 211-215; (b) S. Fujimoto, H. Yasui and Y. Yoshikawa, J. Inorg. Biochem., 2013, 121, 10-15.

24 D. Rehder, J. C. Pessoa, C. F. Geraldes, M. M. Castro, T. Kabanos, T. Kiss, B. Meier, G. Micera, L. Pettersson, M. Rangel, A. Salifoglou, I. Turel and D. Wang, J. Biol. Inorg. Chem., 2002, 7, 384-396.

25 T. Koleša-Dobravc, E. Lodyga-Chruscinska, M. Symonowicz, D. Sanna, A. Meden, F. Perdih and E. Garribba, Inorg. Chem., 2014, 53, 7960-7976.

26 W. Trakarnpruk and P. Hoonsart, Chin. J. Catal., 2007, 28, 290-292.

27 (a) Z. Otwinowski and W. Minor, Methods Enzymol., 1997, 276, 307-326; (b) CrysAlis PRO, Agilent Technologies, Yarnton, England, 2013.

28 (a) G. M. Sheldrick, Acta Crystallogr., Sect. C: Struct. Chem., 2015, 71, 3-8; (b) A. Altomare, M. C. Burla, M. Camalli, G. L. Cascarano, C. Giacovazzo, A. Guagliardi, A. G. G. Moliterni, G. Polidori and R. Spagna, J. Appl. Crystallogr., 1999, 32, 115-119.

29 M. Nakai, H. Watanabe, C. Fujiwara, H. Kakegawa, T. Satoh, J. Takada, R. Matsushita and H. Sakurai, Biol. Pharm. Bull., 1995, 18, 719-725.

30 (a) S. I. V. Judge and C. T. Bever Jr., Pharmacol. Ther., 2006, 111, 224-259; (b) M. H. Rabadi, K. Kreymborg and A. S. Vincent, Drugs $R \& D, 2013,13,175-181$.

31 K. Nakamoto, Infrared and Raman Spectra of Inorganic and Coordination Compounds, Wiley, New York, 4th edn, 1986.

32 A. W. Addison, T. N. Rao, J. Reedijk, J. van Rijn and G. C. Verschoor, J. Chem. Soc., Dalton Trans., 1984, 1349-1356.

33 (a) T. Jakusch, J. Costa Pessoa and T. Kiss, Coord. Chem. Rev., 2011, 255, 2218-2226; (b) S. Mehtab, G. Gonçalves, S. Roy, A. I. Tomaz, T. Santos-Silva, M. F. A. Santos, M. J. Romão, T. Jakusch, T. Kiss and J. C. Pessoa, J. Inorg. Biochem., 2013, 121, 187-195; (c) G. Gonçalves, I. Tomaz, I. Correia, L. F. Veiros, M. M. C. A. Castro, F. Avecilla, L. Palacio, M. Maestro, T. Kiss, T. Jakusch, M. H. V. Garcia and J. C. Pessoa, Dalton Trans., 2013, 42, 11841-11861; (d) D. Sanna, M. Serra, G. Micera and E. Garribba, Inorg. Chem., 2014, 53, 1449-1464; (e) D. Sanna, G. Micera and E. Garribba, Inorg. Chem., 2013, 52, 11975-11985; ( $f$ ) E. Lodyga-Chruscinska, G. Micera and E. Garribba, Inorg. Chem., 2011, 50, 883-899; $(g)$ D. Sanna, G. Micera and E. Garribba, Inorg. Chem., 2011, 50, 3717-3728; (h) D. Sanna, G. Micera and E. Garribba, Inorg. Chem., 2009, 48, 5747-5757. 34 (a) T. Koleša-Dobravc, A. Meden and F. Perdih, Monatsh. Chem., 2014, 145, 1263-1275; (b) T. Koleša-Dobravc, A. Meden and F. Perdih, Acta Chim. Slov., 2015, 62, 261-271; (c) T. Koleša-Dobravc, A. Meden and F. Perdih, New J. Chem., 2015, 39, 4265-4277.

35 G. Süss-Fink, S. Stanislas, G. B. Shul'pin, G. V. Nizova, H. Stoeckli-Evans, A. Neels, C. Bobillier and S. Claude, J. Chem. Soc., Dalton Trans., 1999, 3169-3175. 
36 M. Melchior, K. H. Thompson, J. M. Jong, S. J. Rettig, E. Shuter, V. G. Yuen, Y. Zhou, J. H. McNeill and C. Orvig, Inorg. Chem., 1999, 38, 2288-2293.

37 L.-C. Du, Acta Crystallogr., Sect. E: Struct. Rep. Online, 2009, 65, m106.

38 C. Sun, X. Zheng and L. Jin, J. Mol. Struct., 2003, 646, 201-210.

39 T. A. Zevaco, H. Görls and E. Dinjus, Inorg. Chim. Acta, 1998, 269, 283-286.

40 D. Dobrzyńska, T. Lis and L. B. Jerzykiewicz, Inorg. Chem. Commun., 2005, 8, 1090-1093.

41 L. Croitor, D. Chisca, E. B. Coropceanu and M. S. Fonari, Acta Crystallogr., Sect. E: Struct. Rep. Online, 2013, 69, m454.

42 C.-L. Chen, J. M. Ellsworth, A. M. Goforth, M. D. Smith, C.-Y. Su and H.-C. zur Loye, Dalton Trans., 2006, 5278-5286.

43 (a) H.-L. Seng, S.-T. Von, K.-W. Tan, M. J. Maah, S.-W. Ng, R. N. Z. R. A. Rahman, I. Caracelli and C.-H. Ng, BioMetals, 2009, 23, 99-118; (b) J.-C. Daran, P. Lemoine and B. Viossat, Acta Crystallogr., Sect. C: Cryst. Struct. Commun., 2002, 58, $\mathrm{m} 210-\mathrm{m} 212$.
44 Y. Kojima, Y. Yoshikawa, E. Ueda, N. Kishimoto, M. Tadokoro and H. Sakurai, Bull. Chem. Soc. Jpn., 2005, 78, 451-455.

45 N. Okabe and Y. Muranishi, Acta Crystallogr., Sect. E: Struct. Rep. Online, 2003, 59, m244-m246.

46 R. Ferreirós-Martínez, D. Esteban-Gómez, É. Tóth, A. de Blas, C. Platas-Iglesias and T. Rodríguez-Blas, Inorg. Chem., 2011, 50, 3772-3784.

47 Y.-C. Liang, M.-C. Hong, R. Cao and J.-B. Weng, Chin. J. Struct. Chem., 2001, 20, 455-458.

48 Y.-W. Tao and Y. Wang, Acta Crystallogr., Sect. E: Struct. Rep. Online, 2011, 67, m908.

49 Y. Yoshikawa, H. Sakurai, D. C. Crans, G. Micera and E. Garribba, Dalton Trans., 2014, 43, 6965-6972.

50 X. Yang, K. Wang, J. Lu and D. C. Crans, Coord. Chem. Rev., 2003, 237, 103-111.

51 A. Levina, A. I. McLeod, S. J. Gasparini, A. Nguyen, W. G. M. De Silva, J. B. Aitken, H. H. Harris, C. Glover, B. Johannessen and P. A. Lay, Inorg. Chem., 2015, 54, 7753-7766. 